\title{
Trend Analysis of Climatic and Hydrological Parameters in Ajora-Woybo Watershed, Omo-Gibe River Basin, Ethiopia
}

Meseret Bekele Toma ( $\square$ meseretbekelet@gmail.com )

Hawassa University Institute of Technology https://orcid.org/0000-0002-1555-5581

\section{Mulugeta Dadi Belete}

Hawassa University

Mihret Dananto Ulsido

Hawassa University

\section{Research}

Keywords: climatic parameters, River discharge, trend detection, Ajora-Woybo watershed

Posted Date: December 16th, 2021

DOI: https://doi.org/10.21203/rs.3.rs-1084418/v1

License: (1) (i) This work is licensed under a Creative Commons Attribution 4.0 International License.

Read Full License 


\title{
Trend Analysis of Climatic and Hydrological Parameters in Ajora- Woybo Watershed, Omo-Gibe River Basin, Ethiopia
}

\author{
Meseret Bekele Toma; Mulugeta Dadi Belete; Mihret Dananto Ulsido \\ Faculty of Biosystems and Water Resources Engineering, Institute of Technology, Hawassa \\ University, Ethiopia
}

\section{Correspondent author}

Meseret Bekele Toma, E-mail; meseretbekelet@gmail.com

\begin{abstract}
Background: Identifying hydro-meteorological trends is basic for assessing change in climate and river discharge at watershed level. This study examined the long-term trends of rainfall, temperature, and discharge in the annual, monthly and seasonal time scale of Ajora-Woybo watershed in Ethiopia. The data span of rainfall and temperature is between 1990 and 2020 and that of discharge is between 1990 and 2015. Homogeneity test was performed by using Pettit and SNHT tests. Then Mann-Kendall and Sen's slope test for trend analysis and different variability measures were used.

Results: Results indicate that inhomogeneity was detected in annual rainfall data of Angacha and Areka stations. On annual basis, rainfall and discharge exhibited insignificant trends over time while showing a general decreasing pattern. On monthly basis, February and March were found to have significantly decreasing trend for rainfall. During the Kiremt season, rainfall increases and discharge decreases insignificantly. In contrast, maximum, minimum and mean annual temperatures exhibited significant trends with annual increment of $0.04^{\circ} \mathrm{C}, 0.01^{\circ} \mathrm{C}$, and $0.025{ }^{\circ} \mathrm{C}$ per year respectively. Correlations of discharge with both temperature and rainfall have found to be weak in this study.

Conclusions: This trend, combined with population growth and increasing demand of water for agricultural activities exacerbates competing demands for water resources. Caution is therefore required when it comes to developing appropriate measures for the planning and sustainable development of the water resources in the watershed.
\end{abstract}

Key words: climatic parameters, River discharge, trend detection, Ajora-Woybo watershed 


\section{Background}

Nowadays, the global hydrological cycle has been responding to the observed effects of global warming (IPCC, 2014), which include an increasing atmospheric water vapor content and changing precipitation patterns (Belay et al., 2021). In Sub-Saharan Africa, hydro-meteorological variables experienced significant warming, especially droughts and floods, are the most common forms of natural disasters (Serdeczny et al., 2016). For Ethiopia, climate change impacts on river basins are of major concern in view of the sustainability of water resources and agricultural production (Belay et al., 2021). Ethiopia is vulnerable to climate variability, and climate change is likely to increase the frequency and magnitude of disasters (Fazzini et al., 2015). Adverse impacts of climate change may worsen existing social and economic challenges of the whole country (Conway, 2011; Gizachew and Shimelis, 2014), particularly where people are dependent on resources that are sensitive to climate change and rain-fed agriculture (Addisu et al., 2015). Thus, understanding climate variability and change and its relation with water resource at a local scale is very important for economic growth and formulation of adaptation strategies that will increase the resilient of the local community (Adeba, 2015; Philip, 2019). It is therefore important for society to be prepared to reduce the vulnerability level of the community at local scale (Araya-Osses et al., 2020).

Climate change is altering surface water resources through changes in spatiotemporal distribution and magnitude (Chen et al., 2020), which will affect regional water balance and ecological environment (Asfaw et al., 2018; Witte et al., 2012). The change is based on time (real upward or downward tendency), namely the climate can change in the form of cycles, both daily, seasonal, annual, and decades (Fazzini et al., 2015; Bodian et al., 2020). According Twisa and Buchroithner (2019), the change in precipitation alters the hydrological systems, affecting water resources in both spatially and temporally. Concerns about climate change impacts on the behavior of hydrologic variables tend to extensive studies to specify trends of climatic and hydrological variables (Belihu et al., 2018; Emmanuel et al. 2019; Mubialiwo et al., 2020). Therefore, planning for water resources management projects depends on observational and historical climatic and hydrologic data (Chen et al. 2014). Integrated water resources management in a river watershed described in this case studies is essential for the economic welfare of the society and healthy environmental function as well as powerful analysis techniques necessary to identify hydrological behavior of watersheds. Because according to Adeba (2015) water resources development is essential to bring about sustainable development and overall economic growth.

The climate system of Ethiopia is strongly influenced by complex topography of the country, seasonal migration of the InterTropical Convergence Zone (ITCZ) and associated atmospheric circulations (Fazzini et al., 2015). Spatially, Ethiopia has a diverse climate system, ranging from the semi-arid desert type (bereha) in the lowlands to the cool type (wurch) in the mountainous regions > 3300 amsl: which traditionally classified in to five agro-ecological zones. Particularly, the study area entertains in three agro-ecologies: Lowland (kolla) with elevation less than $1500 \mathrm{~m}$ a.s.l. in the lower part of the watershed; midland (woinadega) with elevation $1500 \mathrm{~m}-2300 \mathrm{~m}$ a.s.l. in the middle half of 
the watershed; and cool temperate climate (dega) in the mountainous areas of the watershed. These diversified climate state have significant social, economic and environmental opportunities. However, empirical evidences have been warning that present global climate changes have knocking the ecological and livelihoods systems of the country, and the study area is not exceptional.

There exists a dearth of empirical evidences regarding the relationship between global climate change and water resource at local and household levels in Ethiopia. For example, Temesgen et al. (2008) conducted quantitative assessment of vulnerability due to climate change in Ethiopia based on the Ricardian approach. The study found that both the decrease in rainfall and the increase in temperature were detrimental to Ethiopian agriculture. According to the NMA (2007; 2014) revealed that in Ethiopia climate variability and change in the country is mainly manifested through the variability and decreasing trend in rainfall and increasing trend in temperature. Besides, rainfall and temperature patterns show large regional differences. In addition, Ethiopian climate is also characterized by a history of climatic extremes such as droughts and floods. The average annual minimum temperature in the country has increased by about $0.250^{\circ} \mathrm{C}$ every 10 years, while the average annual maximum temperature has increased by about $0.10^{\circ} \mathrm{C}$ per decade. The average annual rainfall of the country showed a very high level of variability over the past 50 years even though the trend remained more or less constant. Studies also indicate that mean temperature and precipitation have been changing over time. Rainfall is historically highly variable and there is no clear trend in the amount of rainfall over time (Serdeczny et al., 2016; Woldesenbet and Elagib, 2021). Recently, Woldesenbet and Elagib (2021) showed stream flow trends increased significantly on annual and seasonal scales at most of the gauging stations in the upper Blue Nile River basin. Asfaw et al. (2018), showed intra- and inter-annual variability of rainfall in northern Ethiopia of Woleka sub basin. Jaweso et al. (2019), in Upper Omo-Gibe River revealed rainfall exhibited statistically decreasing trends at a mean annual time scale, while seasonal rainfall depicted heterogeneous results in both directions. For the majority of the stations, air temperature showed statistically significant increasing trends. There is generally a decreasing trend in stream flow.

This continuous change in climate and hydrological pattern requires continuous investigation and analysis of trends with change point detection in climatic variables in all the regions of the world specifically at the local level to understand hydrological behavior of the watershed. The trend of climate and hydrological changes are detected through change in the average pattern of the climate parameters such as rainfall, temperature and River discharge. Analysis of temperature and precipitation variability is the very important side influencing on climate variability and extremes (Bhuyan et al., 2018; Tesfaye et al., 2019). Therefore, an examination on rainfall, temperature and hydrological behavior is important for planning and the prediction of future climate conditions (Bhuyan et al., 2018), although this study consider only observed and historical climate condition for the last three decades. Studies conducted on the analysis of climate and hydrological parameters across the Omo-Gibe Basin are lacking particularly in Ajora-Woybo watershed. Thus, long-term studies on changes in climatic and hydrological variables in such watersheds can help to improve 
our understanding of the watershed response to climatic changes. Therefore, more research in this respect needed at a local scale in order to determine the nature of trend and level of significance. Therefore, the aim of this paper was to investigate the trends and changes of climatic and hydrological parameters over Ajora-Woybo watershed from 1990 to 2020. The objectives of the study are (1) to analyze rainfall, temperature and discharge trends, (2) to examine temporal variations in rainfall, temperature and discharge, and (3) to evaluate the relationship between climatic parameters and river discharge. The policymakers, investors, planners and even communities (other end-users) need this study findings on the future climate and hydrology characteristics of the area and, so that they can prepare for the expected trend and change. This study will also support decision making in watershed and water resource-based climate change strategies.

\section{Materials and methods}

\section{Description of the study area}

The Omo-Gibe River basin has an area of $79,000 \mathrm{~km}^{2}$ with a length of $550 \mathrm{~km}$ and an average width of $140 \mathrm{~km}$ and covers parts of two national regional states, the SNNPR and the Oromia Region. The average total annual discharge from the River basin is estimated to be about 16.6 billion cubic meters (BMC). The Basin is Ethiopian's second largest river system after that of the Blue Nile, accounting for $14 \%$ of Ethiopian's annual runoff. The main tributaries of the Basin are from northeast Walga, Wabe, Wariness, Derghe, and south-west Gilgel-Gibe and Gojeb Rivers. From the eastern side of the middle and lower Omo-Gibe catchment the Ajancho, Soke, Shapa, Woybo, Sana, Deme and Zage Rivers are the main tributaries. Closed River basin flows into Lake Turkana in Kenya that forms its southern boundary.

Ajora-Woybo watershed elected as case study for this research is one of the major watersheds in Omo-Gibe Basin and is situated in the eastern side of the middle Omo-Gibe Basin. The study regions i.e. Ajora-Woybo watershed contain four perennial Rivers (Ajancho, Soke, Shapa and Woybo Rivers) that are flowing downstream lower valley eventually forms two rivers i.e. Ajora and Woybo (from where the name of watershed is given) finally joining into Gibe III dam reservoir. In addition, many small intermittent tributaries drain into the Rivers. The watershed covers an area of some $1723.5 \mathrm{~km}^{2}$ with a perimeter of $336.8 \mathrm{~km}$. The watershed lies between $7^{0} 2^{\prime} 0^{\prime}$ ' $\mathrm{N}$ and $7^{0} 26^{\prime} 0^{\prime}$ ' $\mathrm{N}$ latitude and between $37^{\circ} 32^{\prime} 0^{\prime}$ ' $\mathrm{E}$ and $37^{\circ} 58^{\prime} 0^{\prime}$ ' $\mathrm{E}$ longitude. The big irrigation dam project including the proposed dam under construction in the watershed was planned to have 10,000 hectares of land cultivated for which Ajancho and Woybo Rivers are the main source.

The topography of the watershed varies considerably (Worku et al. 2014). The northern two-thirds of the watershed have mountainous to hilly terrain cut by deeply incised gorges of the Omo, Ajancho-Soke, and Gilgel-Gibe Rivers. The lowest and highest of the watershed lies at an altitude greater than 731 masl with 3036 masl maximum elevation respectively. A gauging site is located at each part of the Rivers (i.e. for Ajancho, Soke, Shapa and Woybo) with in the watershed. 
Climate of Ethiopia is classified into five climate zones based on the altitude and temperature. Each zone has its own rainfall pattern and agricultural production system. The climate of the AjoraWoybo watershed varies from a hot arid climate in the southern part of the floodplain to a tropical humid one in the highlands that include the extreme north and northeastern part of the watershed. Between these extremes, and for most of the watershed, the climate is tropical sub humid. Rainfall varies from over $1900 \mathrm{~mm}$ per year in the northern areas to less than $300 \mathrm{~mm}$ per year in the south. In addition, the rainfall regime is bimodal in the watershed. The mean annual temperature in the watershed varies from $16^{\circ} \mathrm{c}$ in the highlands of the north to over $29^{\circ} \mathrm{c}$ in the lowlands of the south.

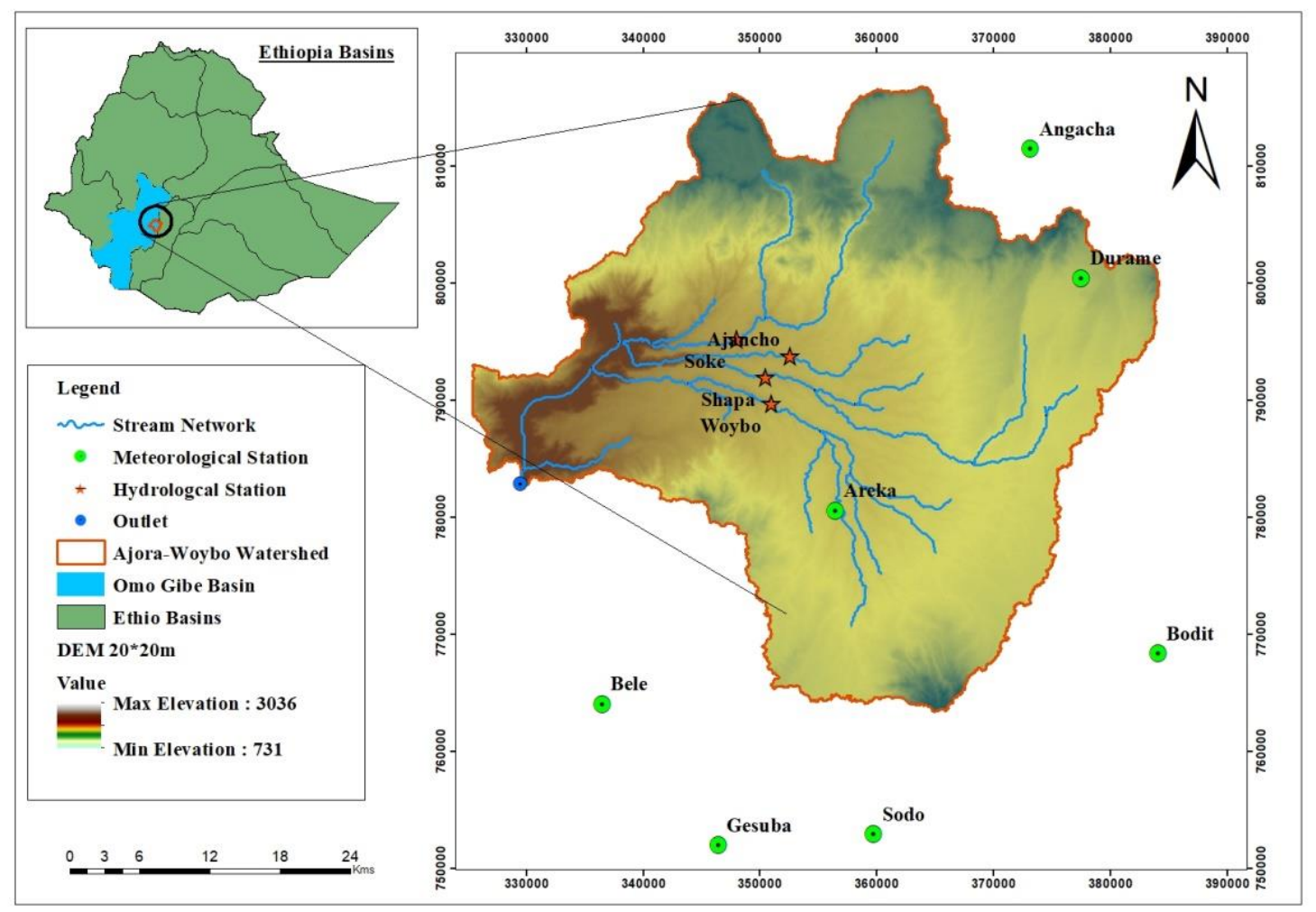

Figure 1. Location map of the study area

\section{Materials}

\section{Data pre-processing}

The daily meteorological (rainfall and temperature) data from 1990 to 2020 and hydrological data from 1990 to 2015 were collected from National Meteorological Agency (NMA) and Ministry of Water and Energy office of Ethiopia. 
Table 1. General characteristics of meteorological stations

\begin{tabular}{|l|l|l|l|l|l|l|l|}
\hline No. & Stations & Latitude & Longitude & Elevation $(\mathrm{m})$ & RF & Temp. & Missing (\%) \\
\hline 1 & Angacha & 7.34 & 37.85 & 2317 & A & A & 2.56 \\
\hline 2 & Areka & 7.06 & 37.70 & 1752 & A & NA & 3.74 \\
\hline 3 & Bele & 6.91 & 37.52 & 1240 & A & NA & 1.29 \\
\hline 4 & Bodit & 6.95 & 37.95 & 2043 & A & A & 0.2 \\
\hline 5 & Durame & 7.24 & 37.89 & 2116 & A & A & 2.4 \\
\hline 6 & Gesuba & 6.66 & 37.63 & 1650 & A & A & 1.2 \\
\hline 7 & Sodo & 6.81 & 37.73 & 1854 & A & A & 0.1 \\
\hline
\end{tabular}

$\mathrm{A}=$ available $\mathrm{NA}=$ not available

\section{Methods}

\section{Filling of missed data using multiple imputations (MI)}

Multiple imputations are a filling method that provides valid statistical inferences under missing at random condition. The MD (missing data elimination techniques) rates using standard regression procedures and then combine the results of these analyses to obtain the final result, as shown in equation (1) (Rubin, 1987; Schafer, 1997). The multiple imputations have been implemented in software such as XLSTAT (Armanous et al., 2020; Ekeu-Wei et al., 2018). MI is widely used method in hydrology and its advantages were does not overestimate error, simulate missing data multiple times (Ekeu-Wei et al., 2018) and leads to best estimation of missing values (Sattari et al., 2017). To apply this method, we can proceed as follows: (i) Find k similar databases for each missing value; then the observed values are used to impute MD. (ii) For each MD (Px), we use data imputations $\mathrm{Pi}$ by applying regression methods to obtain $\mathrm{k}$ different estimate results $\mathrm{Ii}(\mathrm{Px}, \mathrm{Pi})$. (iii) The result Px will be obtained by combining all imputations results Ii using average of all the $\mathrm{k}$ complete data values, that is:

$\mathrm{P}_{\mathrm{x}}=\frac{\sum_{\mathrm{i}=1}^{\mathrm{k}} \mathrm{I}_{\mathrm{i}}\left(\mathrm{P}_{\left.\mathrm{x}, \mathrm{P}_{\mathrm{i}}\right)}\right.}{\mathrm{K}}$

\section{Homogeneity test using Pettit test and Standard Normal Homogeneity Test (SNHT)}

Pettit test: To investigate the existence of the change points/break-point detection in the rainfall and temperature characteristics in time series data different methods can be applied. The Pettit test was used to identify whether or not there is a point change or jump in the data series (Pettit, 1979; Bodian et al., 2020). It is based on the Mann-Whitney two-sample test, allows the detection of a single shift at an unknown time and independent of the distribution of data (Bodian et al., 2020). In addition, many researchers also applied Pettit test in climatic and hydrological time series (e.g. Asfawu et al., 2018; Belihu et al., 2018; Jaweso et al., 2019; Bodian et al., 2020).

It considers a sequence of random variables $\mathrm{x}_{1}, \mathrm{x}_{2}, \ldots, \mathrm{x}_{\mathrm{T}}$, with a change point at $\tau\left(\mathrm{x}_{\mathrm{t}}\right.$ for $\mathrm{t}=1,2, \ldots$, $\tau$ ), and a common distribution function $\mathrm{F} 1(\mathrm{x})$ and $\mathrm{x}_{\mathrm{t}}$ for $\mathrm{t}=\tau+1, \ldots \mathrm{T}$ have a common distribution 
function and $\mathrm{F} 2(\mathrm{x})$, and $\mathrm{F} 1(\mathrm{x}) \neq \mathrm{F} 2(\mathrm{x})$. The null hypothesis $\mathrm{H} 0$ : no change or $\tau=\mathrm{T}$ is tested against the alternative hypothesis Ha: change or $1 \leq \tau \leq \mathrm{T}$ using the non-parametric statistic $\mathrm{KT}=\mathrm{Max} \mid \mathrm{Ut}$, $\mathrm{T} \mid, 1 \leq \tau \leq \mathrm{T}$.

$\mathrm{U}_{\mathrm{t}, \mathrm{T}}=\sum_{\mathrm{t}-1} \sum_{\mathrm{j}=\mathrm{t}-1} \mathrm{Dij}$

$\operatorname{Dij}=\operatorname{sgn}(x i-x j)$ the sgn (xi-xj) computed using equation 3 ,

$\operatorname{sgn}(x i-x j)=\left\{\begin{array}{c}1 \text { if } x i-x j>0 \\ 0 \text { if } x i-x j=0 \\ -1 \text { if } x i-x j<0\end{array}\right.$

Then, the approximate significance probability, $\mathrm{p}(\mathrm{t})$, of a change point then calculated from equation 3 and time series changing points of rainfall and River discharge was checked.

$\mathrm{P} \cong 2 * \exp \left[\frac{-6 \mathrm{~K}_{\mathrm{T}} 2}{\mathrm{~T}^{3}+\mathrm{T}^{2}}\right]$

\section{Standard Normal Homogeneity Test (SNHT):}

The SNHT was developed by Alex-Anderson (1986) to detect a change in a set of precipitation data. The test is applied to a set of ratios comparing observations from one monitoring station to the average of several stations. The ratios are then standardized. Here, the series of Xi corresponds to the standardized ratios. The null and alternative hypotheses are determined as follows:

Ho: The $\mathrm{T}$ variables Xi follow an $\mathrm{N}(0,1)$ distribution.

Ha: Between times 1 and $\mathrm{v}$, the variables follow an $\mathrm{N}\left(\mu_{1}, 1\right)$ distribution, and between $\mathrm{v}+1$ and $\mathrm{T}$, they follow an $\mathrm{N}\left(\mu_{2}, 1\right)$ distribution. The Alex-Anderson statistic defined by:

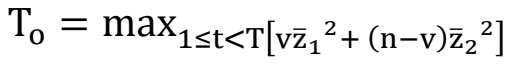

With $\overline{\mathrm{z}}_{1}=\frac{1}{\mathrm{v}} \sum_{\mathrm{t}=1}^{\mathrm{v}} \mathrm{x}_{1}$ and $\overline{\mathrm{z}}_{2}=\frac{1}{\mathrm{n}-\mathrm{v}} \sum_{\mathrm{t}=\mathrm{v}+1}^{\mathrm{T}} \mathrm{x}_{\mathrm{i}}$

The statistic $T_{o}$ derives from a calculation comparing the likelihood of the two alternative models. The model corresponding to $\mathrm{Ha}$ implies that $\mu_{1}$ and $\mu_{2}$ are estimated while determining the $\mathrm{v}$ parameter maximizing the likelihood.

\section{Mann-Kendall trend detection}

Observed rainfall, temperature and discharge trends were analyzed in time series analysis. This is to discern how the historical rainfall and temperature varied over the time 1990 to 2020 with relation to discharge. Daily rainfall, temperature and discharge data were first calculated as monthly rainfall, temperature (maximum, minimum, and mean) and discharge. Monthly values were averaged and summed to obtain seasonal and annual values. In Ethiopia, seasons are classified based on rainfall 
pattern. NMA (2014) states that there are three main seasons: Kiremt (main rainy season from June to September), Belg (small rainy season from February to May) and Bega (dry season from October to January). Trend analyses were carried out on monthly, seasonal and annual basis with reference to other researchers (e.g. Emmanuel et al. 2019; Philip, 2019; Tesfaye et al., 2019). Yue and Wang (2004) pointed out that the significance of the trend depends on the pre-specified significance level, the size of the trend, the sample size, and the amount of variation within a time series. That is, the larger the absolute size of the trend, the more meaningful the tests; the larger the sample size, the more meaningful the tests become. Outliers are well treated by the Seasonal Kendall methods because it uses the rank of the values and the method is usually less affected by the presence of outlier's value (Belihu et al., 2018; Mubialiwo et al. 2020). This makes the test not sensitive to outlier's values.

The non-parametric Mann-Kendall (MK; Kendall, 1975; Mann, 1945) statistics was chosen to detect historical trends for rainfall, temperature and stream flow time series data, as it is widely used for water resource planning and management studies (e.g. Belihu et al., 2018; Emmanuel et al. 2019; Philip, 2019; Mubialiwo et al., 2020). The test based on S statistics and each paired observed values $x j(j>k)$ of the random variable will be inspected to find out whether $x j>x k$ or $x j<x k$.

$\mathrm{S}=\sum_{\mathrm{k}-1}^{\mathrm{n}-1} \sum_{\mathrm{j}=\mathrm{k}-1}^{\mathrm{n}} \operatorname{sgn}(\mathrm{xj}-\mathrm{xk})$

Where $x j$ and $x k$ are the annual data values in years $j$ and $k, j>k$ respectively and $n$ is number of observation.

$\operatorname{sgn}(x j-x k)=\left\{\begin{array}{c}1 \text { if } x j-x k>0 \\ 0 \text { if } x j-x k=0 \\ -1 \text { if } x j-x k<0\end{array}\right.$

$\mathrm{S}$ is normally distributed with mean zero, and Variance,

$\operatorname{var}(\mathrm{S})=\frac{\mathrm{n}(\mathrm{n}-1)(2 \mathrm{n}+5)}{18}$

Computation for $\mathrm{Z}$ score is obtained as:

$z=\left\{\begin{array}{l}\frac{s-1}{\sqrt{v}} \text { if } s>0 \\ 0 \text { if } s=0 \\ \frac{s+1}{\sqrt{v}} \text { if } s<0\end{array}\right.$

For a given level of significance $\alpha$, the null hypothesis of no trend in the time series will be rejected if $Z z>1-\alpha$. More specifically, $Z>z 1-\alpha$ indicates existence of an increasing trend and $Z<z \alpha$ implies a decreasing trend. 
Where, $\operatorname{var}(\mathrm{S})$ is the variance of Mann-Kendall statistic, S. The standardized MK test statistic (Zscore) follows the standard normal distribution with a mean of zero and a standard deviation of one. A positive value of $Z$ indicates an increasing trend (upward trend) while a negative $Z$ value signifies a decreasing trend (downward trend). When the p-value is less than the level of significance $(\alpha)$, the null hypothesis (Ho) is rejected and a statistically significant trend exists in the rainfall, temperature and River discharge time series. If the p-value is greater than $(\alpha)$, the null hypothesis $(\mathrm{Ho})$ is accepted. Failing to reject the null hypothesis does not mean that there is no trend. Rather, it is a statement that the available evidence is not sufficient to conclude that there is a trend (Mubialiwo et al., 2020).

\section{Sen's slope estimator test}

It was used for estimating the magnitude of a trend by putting the linear rate of change and the intercept (Sen, 1968). The slope estimation is given by

$\beta=$ Median $\left[\frac{\mathrm{xj}-\mathrm{xk}}{\mathrm{j}-\mathrm{k}}\right]$ for all $\mathrm{k}<\mathrm{j}$ and $\mathrm{i}=1,2, \ldots, \mathrm{N}$

The median of $N$ values of $\beta_{i}$ gives the Sen's slope of $\beta$, using following equation 12:

$\beta= \begin{cases}\frac{\beta N+1}{2}, & \text { if } N \text { is odd } \\ \frac{\frac{\beta N}{2}+\frac{\beta N+2}{2}}{2}, & \text { if } N \text { is even }\end{cases}$

Where, $x j$ and $x k$ are the sequential data values, and $n$ is the number of the recorded data. A positive value of $\beta$ indicates an upward (increasing) trend, and a negative value indicates a downward (decreasing) trend in the time series.

\section{Coefficient of variation}

The coefficient of variation measures the overall variability of the rainfall, temperature and river discharge in the area of interest from the mean value. It is calculated as the ratio between the standard deviation and the long-term data mean as expressed in equation 13.

$$
\mathrm{CV}(\%)=\left(\frac{\sigma}{\overline{\mathrm{x}}}\right)
$$

Where $\mathrm{CV}$ is the coefficient of variation, $\sigma$ is the standard deviation over the period and $\bar{x}$ is the mean hydro-climatic parameters. Generally, $\mathrm{CV}$ is used to classify the degree of variability of events into three: low $(\mathrm{CV}<20)$, moderate $(20<\mathrm{CV}<30)$, and high $(\mathrm{CV}>30)$. Higher CV shows more variation in parameters and vice versa (Asfaw et al. 2018; Philip, 2019).

\section{Correlation analysis between climate and river discharge}


The relationship between climate variables and changes in river discharge is the subject of ongoing debate (Gedefaw et al., 2018). Moreover, the correlation between climate variables and runoff helps us to estimate their relationships. Pearson correlation coefficients (r) was calculated for the degree of the linear relation between climate variables (rainfall and temperature) with river discharge.

$r=\frac{\sum_{i=1}^{n}(x i-\bar{x})(y i-\bar{y})}{\sqrt{\sum_{i=1}^{n}(x i-\bar{x})^{2}} \sum_{i=1}^{n}(y i-\bar{y})^{2}}$

Where $\mathrm{r}$ is the correlation coefficient, $\mathrm{n}$ is the length of the time series, and $\mathrm{i}$ is the number of years during the analyzed periods 1990-2020. Xi and Yi are the rainfall, temperature and discharge in the year i, respectively, and $\mathrm{X}$ and $\mathrm{Y}$ are the mean rainfall and, temperature and discharge, respectively during the studied periods (Bhuyan et al., 2018; Philip, 2019). The obtained value was ranked into a weak correlation $(0<|\mathrm{r}| \leq 0.3)$, a low correlation $(0.3<|\mathrm{r}| \leq 0.5)$, a moderate correlation $(0.5<|\mathrm{r}|$ $\leq 0.8)$, and a strong correlation $(0.8<|\mathrm{r}| \leq 1)$ (Bayable et al., 2021).

All MK trend tests, Sen's slope, Pettit change-point detections and variability analyses were conducted using the XLSTAT (https://www.xlstat.com) software (Alhaji et al., 2018; Asfawu et al., 2018; Bodian et al., 2020; Abegaz and Mekoya, 2020).

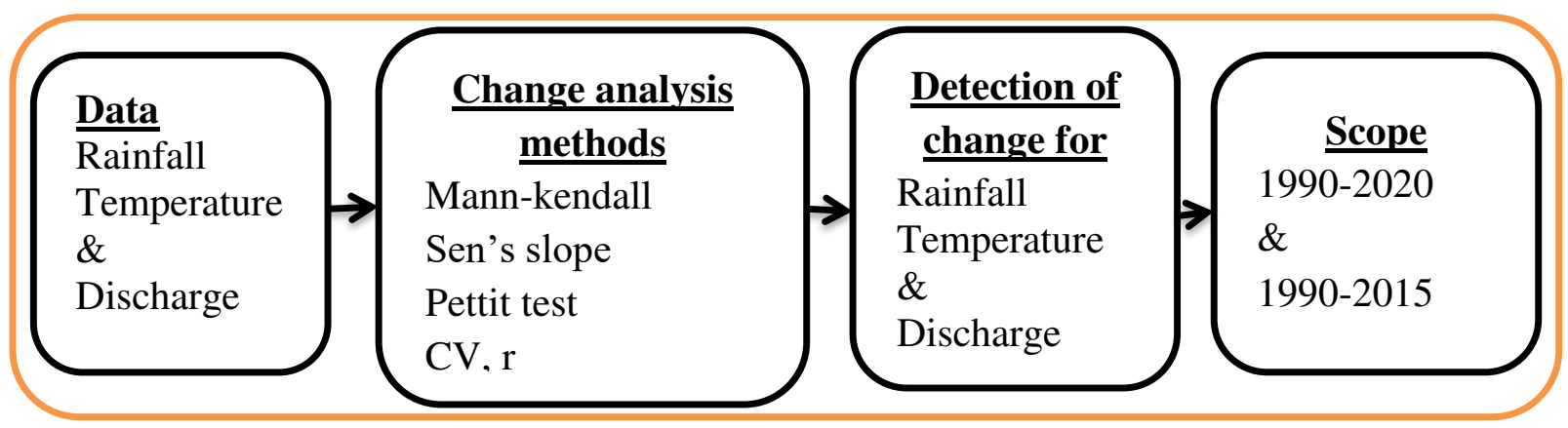

Figure 2. Flow diagram to analyze changes of rainfall, temperature and discharge.

\section{Results and discussion}

\section{Pettit Test and Standard Normal Homogeneity Test (SNHT)}

Homogeneity tests are used to assess the effects of non-climatic factors such as changes in instrumentation, observing practices, station relocations, and station environments on climate time series data (Toreti et al, 2011). For this study, two types of homogeneity test (i.e., Pettit's test and the SNHT test) were performed at 5\% level of significance.

The results of the p-values for the Pettit test are shown in Table 2. Any p-value less than the significance level of $\alpha=0.05$ indicates inhomogeneity in the corresponding time series. For five stations (Bele, Bodit, Durame, Gesuba and Sodo), the null hypothesis was satisfied for all months. Two stations (Angacha and Areka) were found to be inhomogeneous as the p values were less than 
0.05. The $\mathrm{p}$ values obtained from SNHT in the table 2 show null hypothesis of homogeneous data was rejected for $\mathrm{p}$ values less than 0.05 . Five stations showed homogeneous data for all months. The data of two stations were inhomogeneous in the months. The change point detection is may be related to occurrence of El-Niño (2009-2010) and La-Nina (2010-2011) effect in Ethiopia as reported by UNCHA (2016).

Table 2. The $\mathrm{p}$ values obtained from the homogeneity tests for the annual rainfall

\begin{tabular}{|l|l|l|l|}
\hline Stations & Pettit test (p-value) & SNHT test $(\mathbf{p}$-value) & alpha $(\alpha)$ \\
\hline Angacha & $\mathbf{0 . 0 2 4}$ & $\mathbf{0 . 0 1 3}$ & 0.05 \\
\hline Areka & $\mathbf{0 . 0 4 1}$ & $\mathbf{0 . 0 0 1}$ & 0.05 \\
\hline Bele & 0.53 & 0.1 & 0.05 \\
\hline Bodit & 0.67 & 0.89 & 0.05 \\
\hline Durame & 0.1 & 0.21 & 0.05 \\
\hline Gesuba & 0.49 & 0.6 & 0.05 \\
\hline Sodo & 0.71 & 0.79 & 0.05 \\
\hline
\end{tabular}

\section{Detection of change points for annual rainfall}

The Pettit test analysis revealed that rainfall in the upper and central watershed area shown a break point change with different time series in Angacha and Areka station. The change point analysis in annual rainfall showed about $28.5 \%$ of the stations is inhomogeneous. The year of 2009 was year of change and the mean annual rainfall was estimated about $1630 \mathrm{~mm}$ before shift and $1300 \mathrm{~mm}$ after shift at Angacha station. The year of 2013 was year of change and the mean annual rainfall was estimated about $1432 \mathrm{~mm}$ before shift and $1776 \mathrm{~mm}$ after shift at Areka station. Which clearly indicates inconsistency of rainfall data and this may be related to step topography and high vegetation coverage of the area. Generally, except the northern highlands where a major shift of rainfall was exhibited, the remaining parts; the central and southern parts revealed that there was no significant shift/change point/ of annual rainfall.
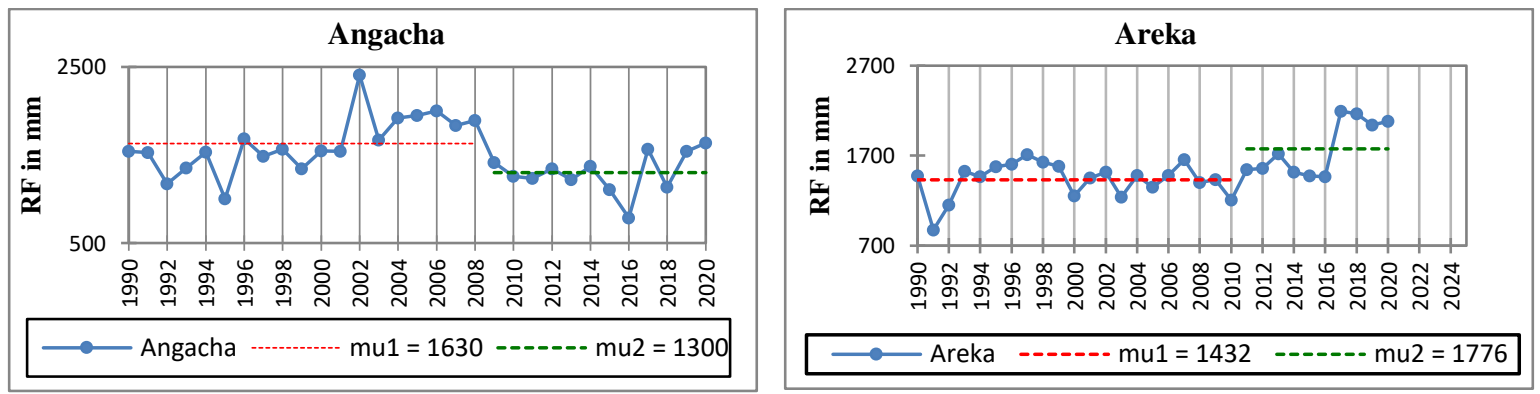

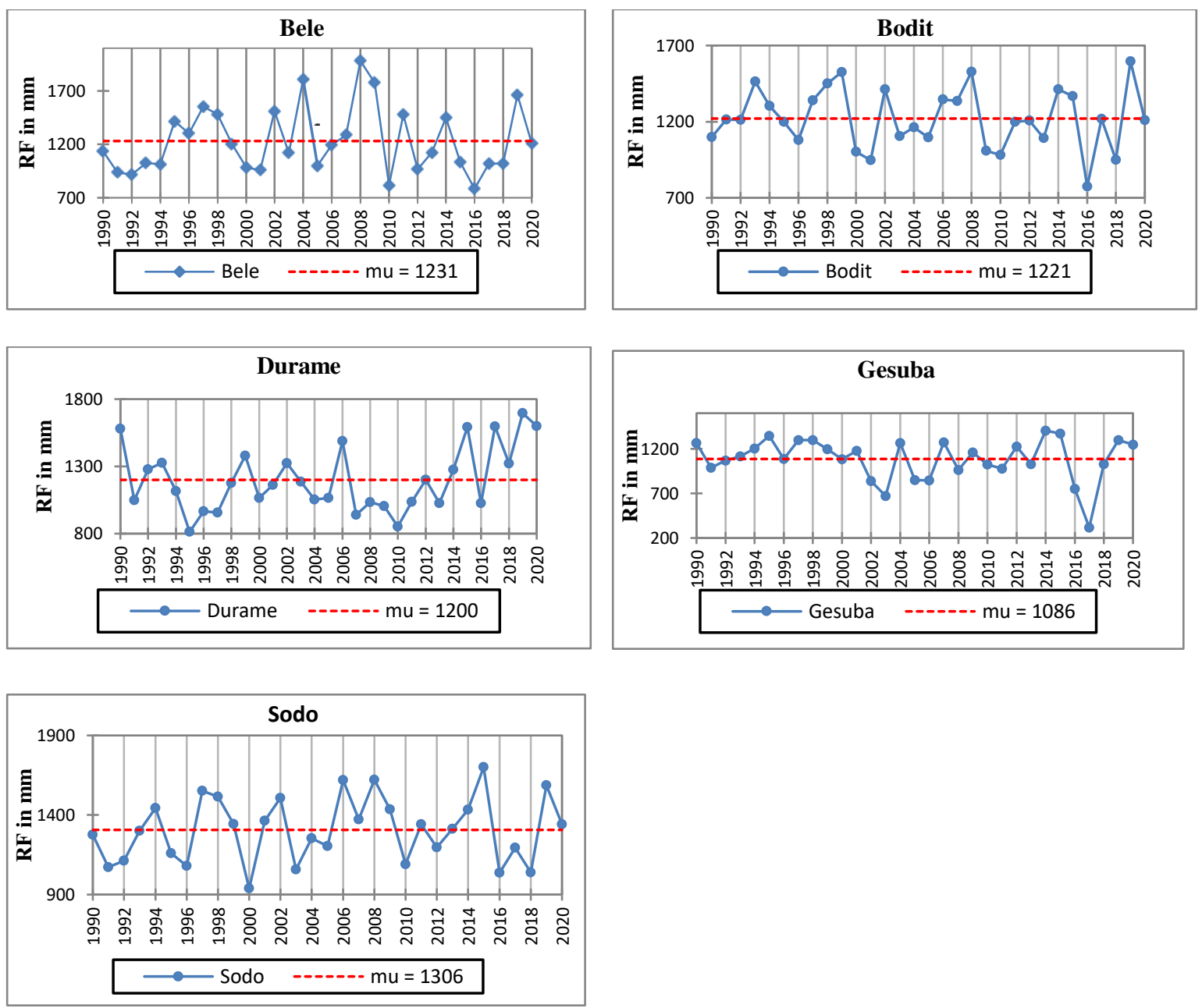

Figure 3. Homogeneity test of the annual mean rainfall at seven stations, where mu is the annual mean rainfall $(\mathrm{mm})$, $\mathrm{mu} 1$ is the annual mean rainfall $(\mathrm{mm})$ before the change point and mu2 is the annual mean rainfall $(\mathrm{mm})$ after the change point

\section{Detection of change points in stream flow time series}

The change point analysis has shown that there is no change point in river discharge of watershed at four gauging stations.
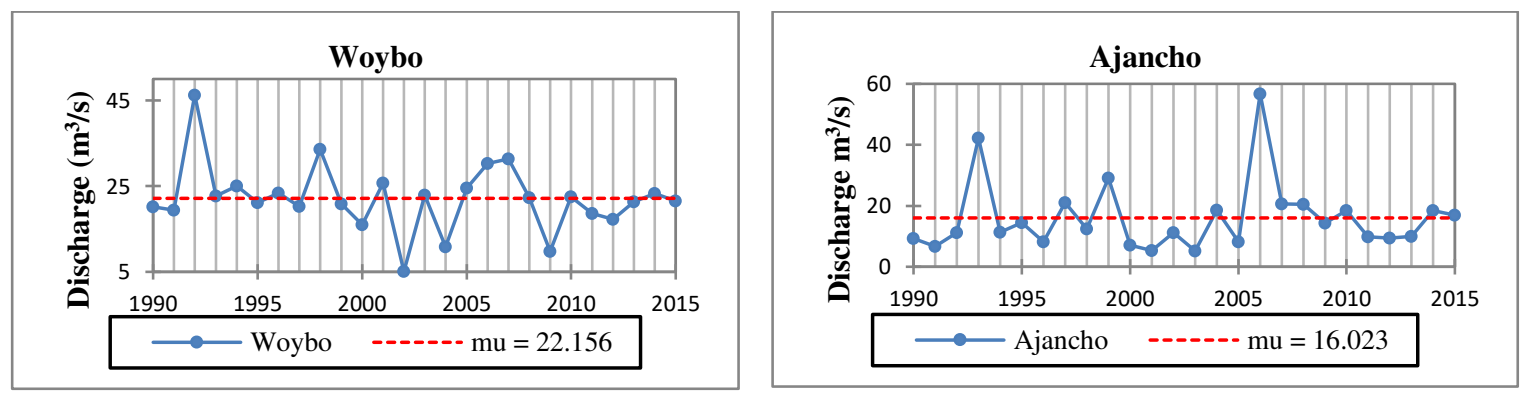

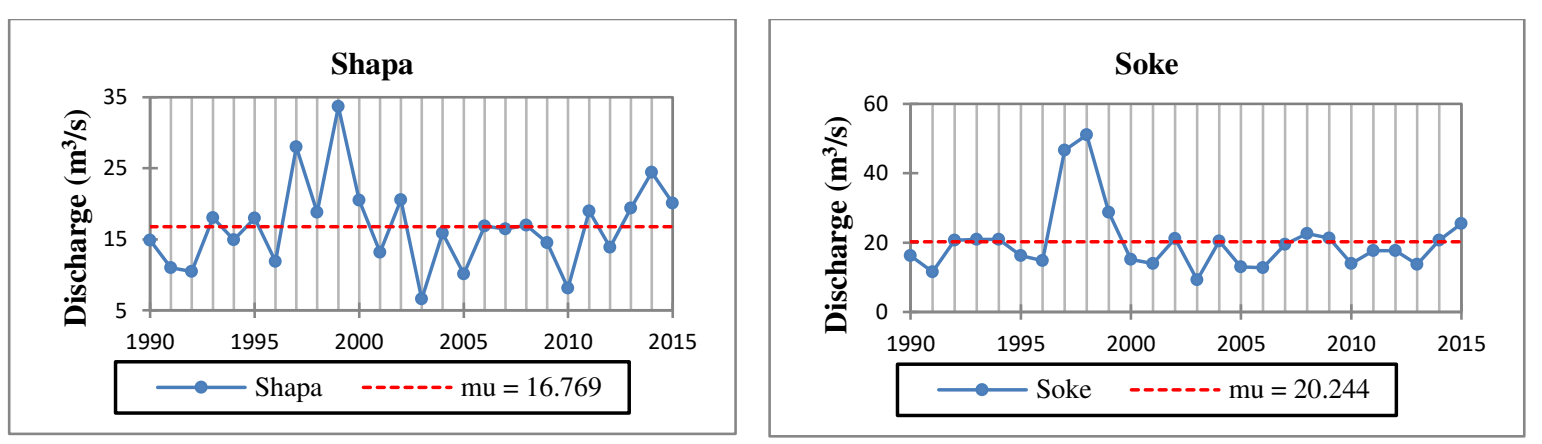

Figure 4. Homogeneity test of the annual mean discharge at four stations, where mu is the annual mean discharge.

\section{Analysis of annual rainfall}

The rainfall analysis from the meteorological stations of in and around Ajora-Woybo watershed was made based on the availability and reliability of the observed gauge stations. The meteorological stations such as Angacha, Areka, Bele, Bodit, Durame, Gesuba and Sodo stations were selected based on the long time availability of data. Accordingly, Angacha and Durame meteorological station from the upper, Gesuba and Sodo stations from the lower and the remaining from central part of sub-watershed have recorded reliable rainfall data for the last 31 years.

The mean annual rainfall of the watershed during the study period was $1271.8 \mathrm{~mm}$ with $140.5 \mathrm{~mm}$ standard deviation and CV of $11 \%$. The minimum and maximum ever-recorded rainfalls were 318 $\mathrm{mm}$ (in 2017 the driest year) in Gesuba station and $2161.8 \mathrm{~mm}$ (in 2019-the wettest year) in Bele station per year. Moreover, June to September is the major rainy season (Kiremt), during this period 48-62 \% of the annual rainfall has received. As indicated below (figure 5) in mean annual rainfall trend, the rainfall is generally homogenous and decreasing but it was insignificant rate. This result agreed with the work done by Jaweso et al. (2019) in southern Ethiopia and Asfawu et al. (2018) in north central Ethiopia. Their finding showed that decreasing RF pattern since about 1981. Viste et al. (2013) and Jaweso et al. (2019) also showed that the decline in precipitation in the southern part of the country is large enough to produce trends on the national level. CV was used to classify the degree of variability of rainfall events. Based on this, watershed rainfall is highly variable in the last two decades, particularly in the Angacha, Bele and Gesuba stations while the remaining stations become less variable.

Table 3. Mean annual rainfall of the watershed

\begin{tabular}{|l|l|l|l|l|l|l|l|}
\hline Stations & Min $(\mathbf{m m})$ & Obs year & Max $(\mathbf{m m})$ & Obs year & Mean & SD & CV $(\boldsymbol{\%})$ \\
\hline Angacha & 786.5 & 2016 & 2107.6 & 2002 & 1489.4 & 305.7 & 20.5 \\
\hline Areka & 875.6 & 1991 & 1712.5 & 1997 & 1399.5 & 168.8 & 12.1 \\
\hline Bele & 784.3 & 2016 & 2161.8 & 2019 & 1243.9 & 343.3 & 27.6 \\
\hline Bodit & 774.3 & 2016 & 1527.8 & 2008 & 1210.9 & 185.1 & 15.3 \\
\hline Durame & 812.8 & 1995 & 1596.0 & 2017 & 1183.5 & 215.5 & 18.2 \\
\hline Gesuba & 318.0 & 2017 & 1404.6 & 2014 & 1081.8 & 232.7 & 21.5 \\
\hline Sodo & 938.2 & 2000 & 1700.3 & 2015 & 1293.5 & 195.8 & 15.1 \\
\hline Mean RF & 918.4 & & 1488.5 & & 1271.8 & 140.5 & 11.0 \\
\hline
\end{tabular}




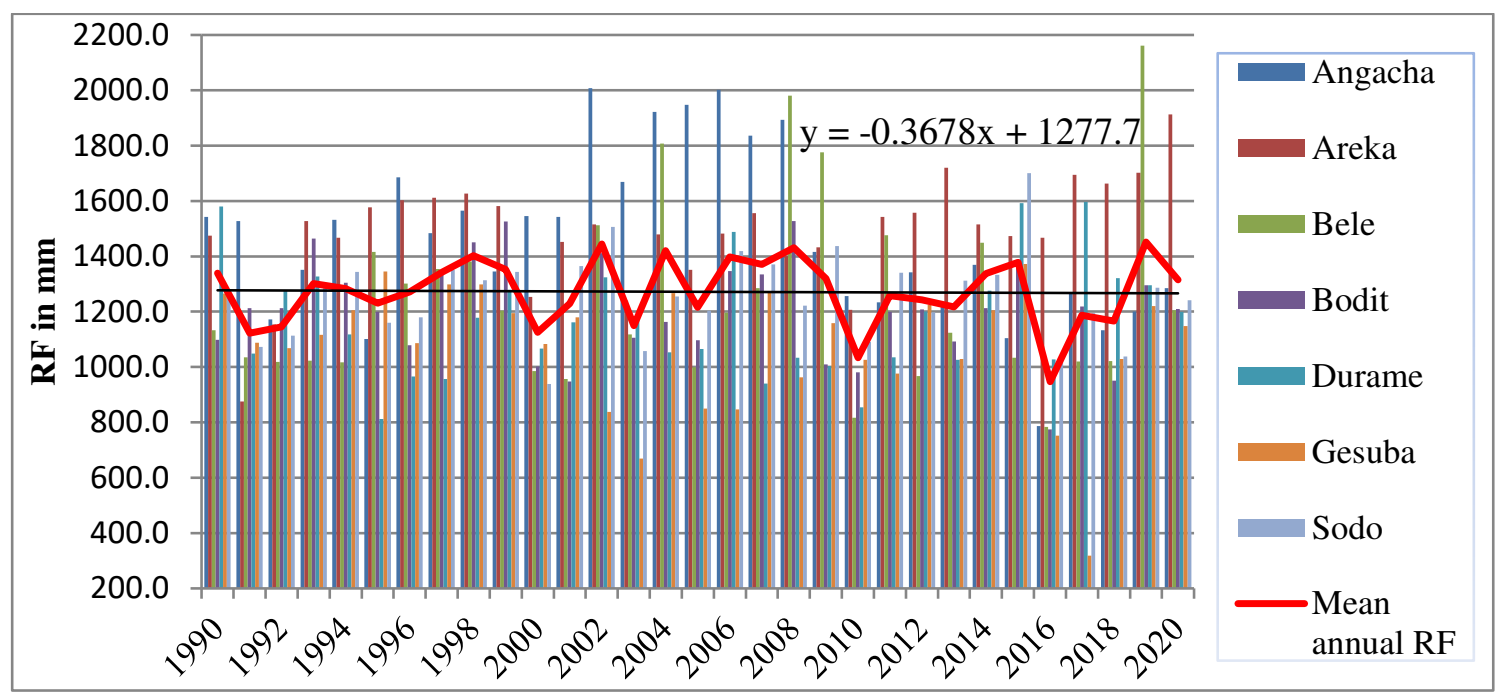

Figure 5. Linear trend of mean annual RF of watershed

\section{Mann-Kendall test result of annual rainfall}

MK test on annual rainfall data of watershed, the results are obtained in the following manner in table 4. The MT is based on the calculation of Kendall's tau (measures of connection between two successive annual rainfall years). The analysis results shows that five of the stations successive annual rainfall years are negatively related and decreasing trend (i.e. Angacha, Bele, Bodit, Durame and Gesuba stations). The remaining two stations show increasing trend but significant only in Areka (0.032) station. Annually, Z-score result was found to be in upward trend in two stations (Areka and Sodo) whereas remaining five stations has downward trend. This study revealed a combination of upward and downward trends and Jaweso et al. (2019) reported similar results in upper Omo-Gibe Basin.

Table 4. MK test result of annual RF

\begin{tabular}{|l|l|l|l|l|l|}
\hline Stations & MK $(\mathbf{S})$ & Kendall tau & P value & Sen's slope & Z-score \\
\hline Angacha & -43 & -0.092 & 0.48 & -6.354 & -1.21 \\
\hline Areka & 127 & 0.273 & $\mathbf{0 . 0 3 2}$ & 13.9 & 1.45 \\
\hline Bele & -31 & -0.067 & 0.61 & -2.24 & -0.24 \\
\hline Bodit & -21 & -0.045 & 0.74 & -0.73 & -0.50 \\
\hline Durame & -65 & -0.14 & 0.28 & -6.42 & -0.63 \\
\hline Gesuba & -21 & -0.045 & 0.73 & -2.12 & -1.31 \\
\hline Sodo & 37 & 0.08 & 0.54 & 3.45 & 0.02 \\
\hline
\end{tabular}

\section{Analysis of monthly and seasonal RF}

The monthly RF is highest in august and lowest in December in all of the stations. The rainfall trend was increased from April to August at all station but it was insignificant rate. Monthly, the RF trend is significantly decreasing in February and March whereas September, November, January, April, 
June and July months show decreasing trend but it was insignificant. December, October and August months show increasing trend but it was insignificant rate.

Seasons are classified based on rainfall pattern in Ethiopia. Seasonally, the precipitation was found to be in Kiremt $(Z=2.78)$, Belg $(Z=-1.74)$, Bega $(Z=-0.26)$, as shown in Table 5. All the three seasons show there is no change of rainfall in the watershed at $95 \%$ confidence level and increasing for Kiremt and decreasing for Belg and Bega trend in the watershed. The seasonal rainfall trend was varies from Kiremt to Bega season $571.3 \mathrm{~mm} / \mathrm{season}$ in Angacha station and $270.3 \mathrm{~mm} / \mathrm{season}$ in Gesuba station. Insignificant rainfall trends may be due to high inter-annual variability (Belihu et al., 2018). The variation of monthly and seasonal RF and declining trend of moisture in time may have a significant impact on different rain-fed agricultural activities.
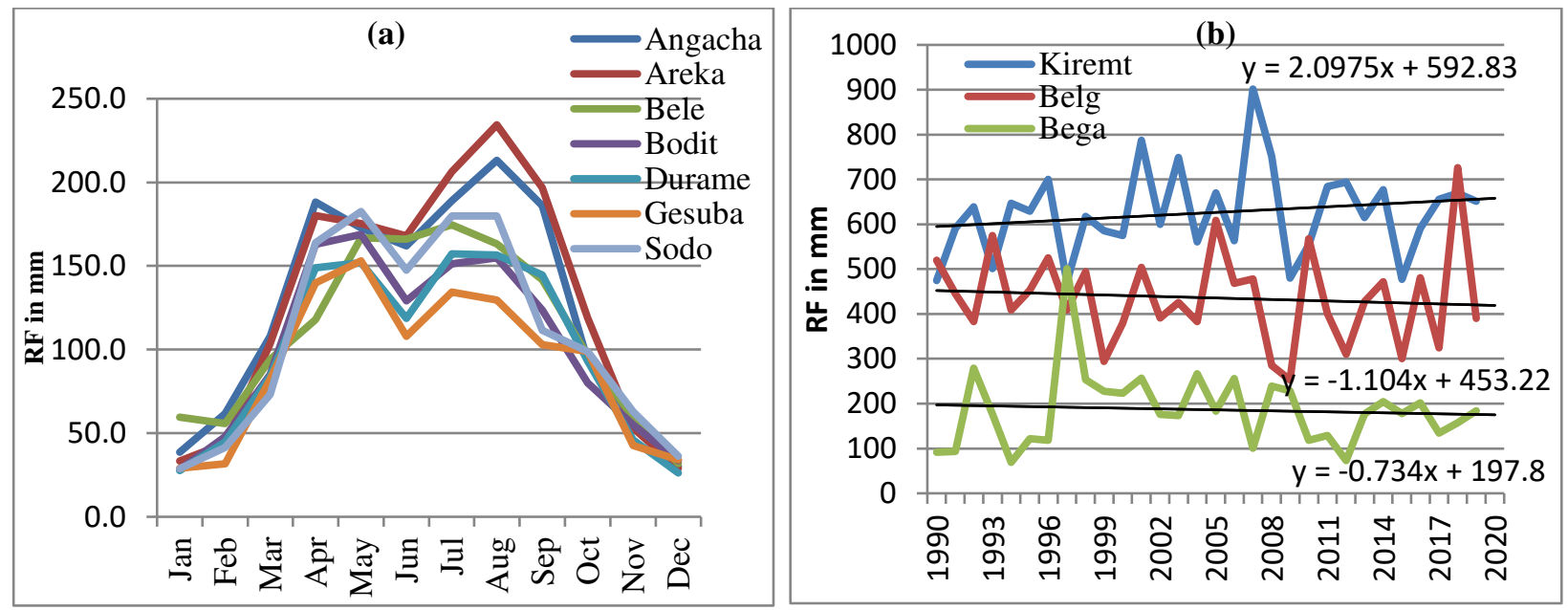

Figure 6. (a) Monthly mean of each stations and (b) Seasonal mean RF trend of the watershed

Table 5. MK test result for monthly and seasonal RF

\begin{tabular}{|l|l|l|l|l|l|}
\hline \multirow{2}{*}{ Time } & \multicolumn{5}{|c|}{ Parameters } \\
\cline { 2 - 6 } & Man-Kendall (S) & Kendall tau & P value & Sen's slope & Z-score \\
\hline Jan & -9 & -0.4 & 0.24 & -1.6 & -0.85 \\
\hline Feb & -13 & -0.6 & 0.05 & -3.4 & -0.78 \\
\hline Mar & -21 & -1 & 0.00 & -5.5 & -0.52 \\
\hline Apr & -7 & -0.3 & 0.38 & -8.5 & -0.11 \\
\hline May & -3 & -0.1 & 0.77 & -3.1 & -0.05 \\
\hline Jun & -11 & -0.5 & 0.14 & -10.6 & -0.20 \\
\hline Jul & -9 & -0.4 & 0.24 & -8.4 & -0.03 \\
\hline Aug & 9 & 0.4 & 0.24 & 11.3 & 0.01 \\
\hline Sep & 13 & -0.6 & 0.07 & -16.5 & -0.19 \\
\hline Oct & 1.0 & 0.05 & 1.0 & 0.6 & 0.47 \\
\hline Nov & -3 & -0.1 & 0.7 & -2.4 & -0.73 \\
\hline Dec & 11 & 0.5 & 0.14 & 0.9 & 0.87 \\
\hline Kiremt & 11 & 0.5 & 0.14 & 43.3 & 2.78 \\
\hline Belg & -13 & -0.6 & 0.06 & -22 & -1.74 \\
\hline Bega & -3 & -0.1 & 0.77 & -3.3 & -0.26 \\
\hline
\end{tabular}




\section{Analysis of annual temperature}

The annual temperature of the maximum (Tmax), minimum (Tmin) and mean (Tmean) along with their standard deviation (SD) and coefficient of variation (CV) have been statistically computed for each stations. The temperature variability between the different years and the average annual temperature is $20.1{ }^{\circ} \mathrm{C}$, while the annual mean maximum temperature reached $25.7{ }^{\circ} \mathrm{C}$ and the annual mean minimum temperature was $14{ }^{\circ} \mathrm{C}$. The maximum temperature trend was significantly increasing at all station except at Angacha station. The minimum temperature trend was significantly increasing at all station except at Gesuba station. The mean temperature trend was significantly increasing at all station except at Angacha and Gesuba station. Temperature, next to rainfall plays a significant role in loss of water over a watershed (Belihu et al., 2018).

The Mann-Kendall test statistics of the Tmax, Tmin, and Tmean are shown in Table 6. Analysis of temperature using the MK test showed that the climate in the watershed has generally warmed over the past three decades. Based on the trend of minimum and maximum temperatures, the magnitude of change was found to be about $0.01{ }^{\circ} \mathrm{C} /$ year to $0.04{ }^{\circ} \mathrm{C} /$ year and the mean values also proved that the watershed has warmed by about $0.025^{\circ} \mathrm{C} /$ year. In addition, the minimum temperature analysis in southern part of the watershed (Bele station) showed an increasing trend particularly in extremes. Similar results were reported by NMA (2007) that revealed the mean minimum temperature has been increasing throughout the country even in the cool months by $0.37{ }^{\circ} \mathrm{C}$ per decade even though our finding less than the country report. The increasing trend of temperature in the area has significant impact on agricultural activities particularly in soil water demand and it has also lead to lose of more water from the watershed due to evapotranspiration. CV of Tmin highly observed in Bodit station (15.7\%) among others.

Table 6. Annual temperature characteristics in Ajora-Woybo watershed.

\begin{tabular}{|l|l|l|l|l|l|l|l|l|}
\hline Stations & Parameters & Min & Max & Mean & SD & CV & P value & slope \\
\hline \multirow{5}{*}{ Angacha } & Tmax & 23 & 25.7 & 24.1 & 0.78 & 3.2 & 0.07 & -0.032 \\
\cline { 2 - 9 } & Tmin & 12.12 & 15.98 & 13.7 & 0.98 & 7.2 & 0.001 & 0.072 \\
\cline { 2 - 9 } & Tmean & 18.1 & 20.8 & 18.9 & 0.8 & 4.2 & 0.12 & -0.043 \\
\hline \multirow{5}{*}{ Bodit } & Tmax & 23 & 25.9 & 24.67 & 0.64 & 2.6 & 0.08 & 0.037 \\
\cline { 2 - 9 } & Tmin & 6.8 & 14.26 & 12.76 & 2 & 15.7 & 0.001 & 0.052 \\
\cline { 2 - 9 } & Tmean & 15.2 & 19.9 & 18.7 & 1.2 & 6.4 & 0.00 & 0.042 \\
\hline \multirow{5}{*}{ Gesuba } & Tmax & 23 & 27.37 & 25.34 & 1.39 & 5.5 & 0.001 & 0.134 \\
\cline { 2 - 9 } & Tmin & 12.12 & 16.34 & 14.39 & 0.94 & 6.5 & 0.001 & 0.085 \\
\cline { 2 - 9 } & Tmean & 17.7 & 21.5 & 19.8 & 1.12 & 5.7 & 0.001 & 0.112 \\
\hline \multirow{5}{*}{ Sodo } & Tmax & 27.7 & 30.27 & 29.17 & 0.725 & 2.5 & 0.01 & 0.051 \\
\cline { 2 - 9 } & Tmin & 12.34 & 15.63 & 14.5 & 0.81 & 5.6 & 0.072 & 0.026 \\
\cline { 2 - 9 } & Tmean & 20.4 & 22.8 & 21.84 & 0.51 & 2.3 & 0.29 & 0.014 \\
\cline { 2 - 9 } & Tmax & 24.63 & 26.37 & 25.43 & 0.42 & 1.7 & 0.002 & 0.028 \\
\cline { 2 - 8 } & Tmin & 13.37 & 15.6 & 14.6 & 0.52 & 3.6 & 0.001 & 0.044 \\
\cline { 2 - 8 } & Tmean & 19 & 20.9 & 20 & 0.42 & 2.1 & 0.001 & 0.35 \\
\hline
\end{tabular}




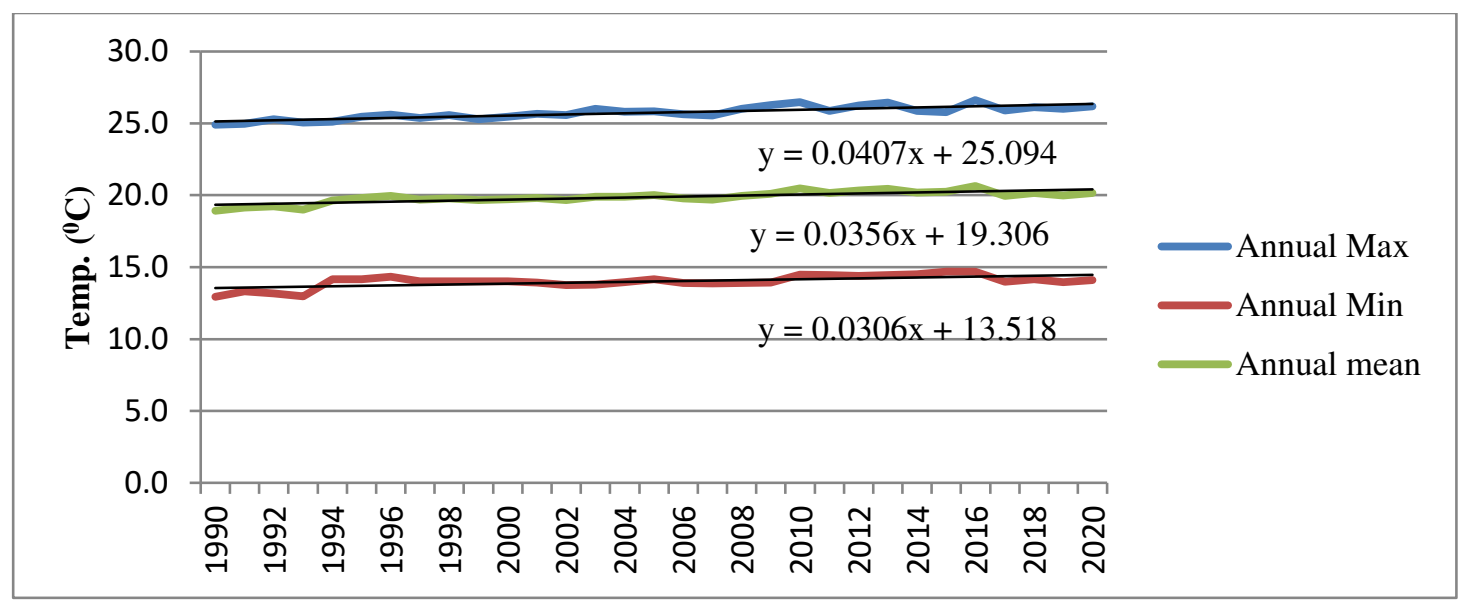

Figure 7. Annual max, min and mean temperature trend of the watershed

\section{Monthly and seasonal temperature}

From the basic temperature data, the monthly and seasonal temperature of the maximum, minimum and mean along with their trend have been statistically computed for each month and the three seasons; Kiremt, Belg and Bega.

The monthly maximum temperature trend was increasing at all station but insignificant change. In addition, the minimum temperature trend showed increasing trend in most stations but decreasing throughout at Bodit station. The maximum monthly temperature is highest in March $31.2{ }^{\circ} \mathrm{C}$ at Gesuba station and lowest in July $21.2{ }^{\circ} \mathrm{C}$ at Bodit station. On the average, August is the coldest month of the year and March is the warmest (only slightly warmer than February). The lowest mean monthly temperature occurred in July $\left(19.28^{\circ} \mathrm{C}\right)$ and the warmest month was March $\left(21.88^{\circ} \mathrm{C}\right)$. In case of seasonal trend analysis, increasing trend of minimum and maximum temperature was detected at all station (figure 9). The Mann-Kendall test statistics of the Tmax, Tmin and Tmean are given in Table 7. The nonparametric estimate for the magnitude of the sen's slope was computed for the significant trends, which certify all the trends in ${ }^{\circ} \mathrm{C} /$ year. Towards the north, the temperature was cooler and to the south, the temperature was warmer. The result of MK test in monthly temperature (maximum and minimum) revealed that the watershed had experienced warming. Mean temperature of Kiremt show decreasing trend but it was insignificant. The slope of the whole months shows that a positive value implying an increase in the mean monthly and seasonal temperature. Belay et al. (2021) revealed similar result in southern Ethiopia. 
Table 7. MK test result of monthly and seasonal Temperature

\begin{tabular}{|l|r|r|l|l|r|l|l|r|l|l|}
\hline \multirow{2}{*}{ Time } & \multirow{2}{*}{ Mean } & \multicolumn{1}{l}{ Tmax } & \multicolumn{1}{l|}{ Tmin } & \multicolumn{2}{l|}{ Tmean } \\
\cline { 3 - 11 } & & Z-score & P & Slope & Z-score & P & Slope & Z-score & P & Slope \\
\hline Jan & 21.12 & 0.86 & 0.2 & 0.7 & 0.65 & 0.6 & 0.48 & 0.63 & 0.13 & 0.4 \\
\hline Feb & 21.76 & 0.35 & 0.2 & 1.0 & 1.09 & 0.48 & 0.7 & 1.43 & 0.13 & 0.72 \\
\hline Mar & 21.88 & 0.29 & 0.2 & 1.0 & 2.13 & 0.23 & 0.54 & 1.58 & 0.08 & 0.7 \\
\hline Apr & 21.04 & 0.36 & 0.2 & 0.7 & 1.09 & 0.08 & 0.41 & 0.54 & 0.08 & 0.53 \\
\hline May & 20.56 & 0.21 & 0.2 & 0.5 & 0.63 & 0.2 & 0.45 & 0.06 & 0.08 & 0.39 \\
\hline Jun & 19.98 & 0.82 & 0.8 & 0.4 & 0.18 & 0.48 & 0.68 & 0.78 & 0.48 & 0.56 \\
\hline Jul & 19.28 & 0.60 & 1 & 0.1 & 0.88 & 0.48 & 0.82 & 1.65 & 0.81 & 0.47 \\
\hline Aug & 19.38 & 0.45 & 0.8 & 0.2 & 1.05 & 0.48 & 0.8 & 1.52 & 0.48 & 0.51 \\
\hline Sep & 19.98 & 0.79 & 0.5 & 0.4 & 0.36 & 0.48 & 0.72 & 0.78 & 0.48 & 0.58 \\
\hline Oct & 20.46 & -0.07 & 0.2 & 0.56 & 0.53 & 0.2 & 0.4 & 0.18 & 0.48 & 0.44 \\
\hline Nov & 20.86 & 0.43 & 0.08 & 0.56 & 0.41 & 0.4 & 0.6 & 0.31 & 0.23 & 0.4 \\
\hline Dec & 20.94 & 0.65 & 0.2 & 0.53 & 0.88 & 0.6 & 0.45 & 0.41 & 0.23 & 0.37 \\
\hline Kiremt & 19.68 & 1.15 & 0.8 & 0.35 & 0.63 & 0.48 & 0.77 & -1.15 & 0.48 & -0.55 \\
\hline Belg & 21.34 & 0.68 & 0.2 & 0.81 & 1.15 & 0.23 & 0.53 & 0.91 & 0.08 & 0.54 \\
\hline Bega & 20.86 & 0.47 & 0.1 & 0.52 & 0.52 & 0.48 & 0.5 & 0.31 & 0.23 & 0.4 \\
\hline
\end{tabular}
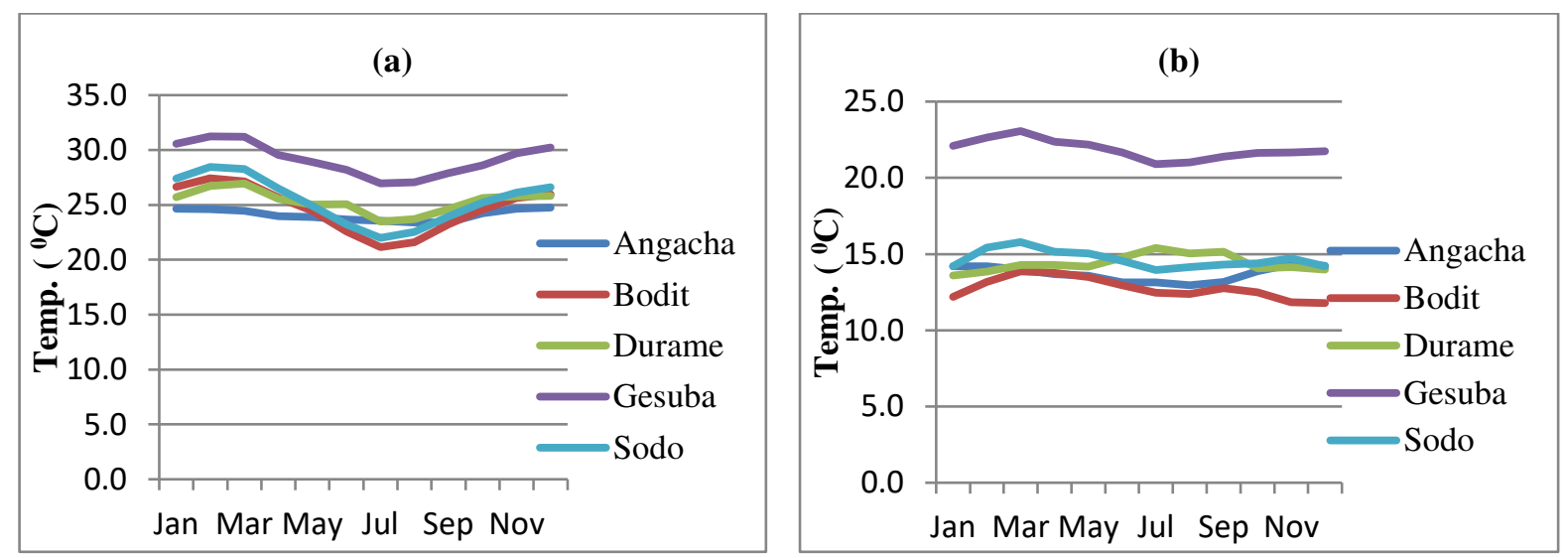

Figure 8. (a) Mean monthly maximum and (b) Mean monthly minimum temperature of the watershed

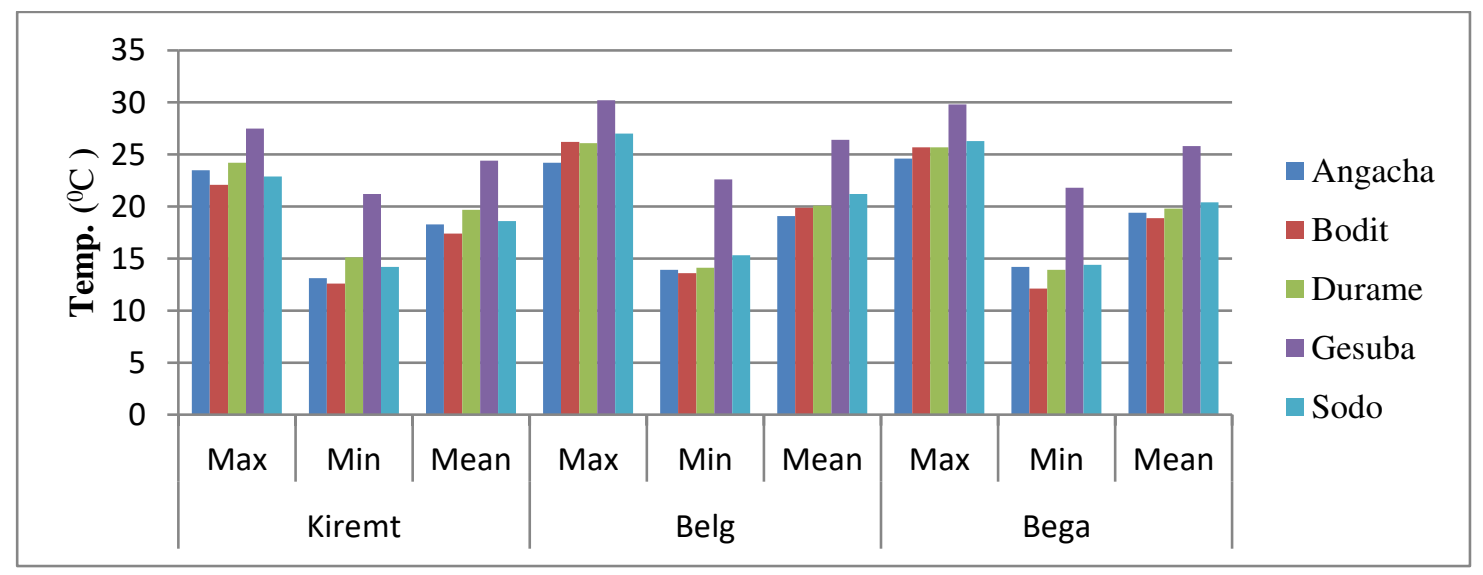

Figure 9. Seasonal maximum, minimum and mean temperature of the watershed 


\section{Analysis of annual river discharge}

In the watershed, long period record was observed at Woybo, Ajancho, Shapa and Soke hydrometric stations. The analysis was done based on the record at four-gauging station. The mean annual flow computed over the period 1990 to 2015 was $22.15 \mathrm{~m}^{3} / \mathrm{s}$ (Woybo), $16 \mathrm{~m}^{3} / \mathrm{s}$ (Ajancho), $16.77 \mathrm{~m}^{3} / \mathrm{s}$ (Shapa) and $20.24 \mathrm{~m}^{3} / \mathrm{s}$ (Soke). Sen's slope showed Ajancho and Shapa stations are upward magnitude whereas the remaining stations show downward magnitude of trend. Maximum flow varies between $33.67 \mathrm{~m}^{3} / \mathrm{s}$ in 1999 to $56.72 \mathrm{~m}^{3} / \mathrm{s}$ in 2006 and minimum has occurred $5.1 \mathrm{~m}^{3} / \mathrm{s}$ in 2002 to $9.2 \mathrm{~m}^{3} / \mathrm{s}$ in 2003. Discharge trends for four gauging stations in the watershed area showed different directions of trends. However, these trends were statistically not significant. These heterogeneous results suggest human interventions (Degefu and Bewket, 2017) and natural causes (Jaweso et al., 2019).

Based on CV analysis, watershed annual River flow is highly variable, especially in the Ajancho station $(72.5 \%)$. The annual trend of discharge showed a decreasing trend which is insignificant with coefficient of determination $\left(\mathrm{R}^{2}=0.0069\right)$. There are numerous authors have reported decreasing trends in the streamflow of Rivers in southern and central Ethiopia. Belihu et al. (2018) reported decreasing trend in Gidabo River basin annually. Gedefaw et al. (2018) informed that there was a decrease in Awash River stream flow. Jaweso et al. (2019) found decreasing trend in stream flow of rivers in Gibe Rivers from year to year.

Table 8. Annual discharge of the watershed

\begin{tabular}{|l|l|l|l|l|l|l|l|}
\hline Stations & Min & Max & Mean & SD & CV & P value & Slope \\
\hline Woybo & 5.08 & 46.26 & 22.15 & 7.9 & 35.7 & 0.57 & -0.9 \\
\hline Ajancho & 5.19 & 56.72 & 16 & 11.6 & 72.5 & 0.54 & 0.13 \\
\hline Shapa & 6.58 & 33.67 & 16.77 & 5.94 & 35.4 & 0.33 & 0.15 \\
\hline Soke & 9.2 & 51.03 & 20.24 & 9.55 & 47.2 & 0.9 & -0.03 \\
\hline Discharge of Watershed & 43.8 & 116.6 & 75.2 & 22.2 & 29.5 & 0.61 & -0.16 \\
\hline
\end{tabular}
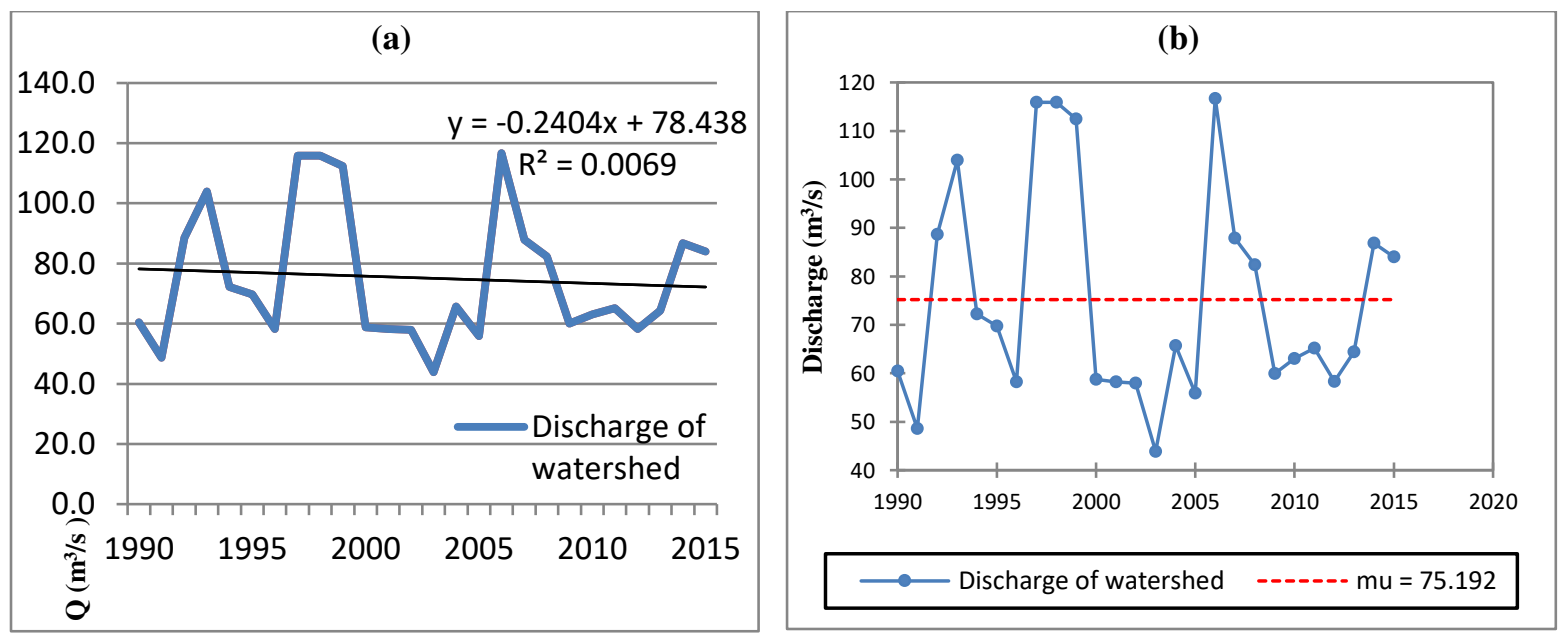
Figure 10. (a) Linear trend and (b) Pettit homogeneity tests of mean annual discharge

\section{Monthly and seasonal Discharge}

The average monthly and seasonal discharge of the Ajora-Woybo watershed from 1990 to 2015 are depicted in figure 11. The highest monthly discharge was seen in September, which is slightly greater than August, and both months lies in Kiremt season. In February, the watershed gets the poor amount of discharge. The mean monthly average discharge was low from January to March, and started to increase in the month of April. MK results reveal that no trend was found in monthly discharge of the watershed. Sen's slope show the month of September and October is upward magnitude whereas the remaining months show downward magnitude of trend. Monthly discharge generally shows decreasing trend except September and October.

Seasonal trend over time at the watershed is shown in figure 11(b). Kiremt season drains the highest amount of water and Belg season drains the lowest amount of waters. The result of trend analysis in discharge at watershed indicates that there is a decreasing trend of seasonal discharge but it was insignificant for three seasons. Similar study conducted at upper Omo-Gibe River Basin indicated that decreasing trend for seasonal stream flow at Gibe at Abelti station gauging station (Jaweso et al., 2019). Generally, the amount of surface water resources of the watershed is decreasing from time to time and this means there will exist a shortage of water for irrigation and operation of hydropower dam (Gibe III) which is mostly dependent on Woybo, Ajancho, Soke and Shapa Rivers. The decreasing trend of discharge in this study may be attributed to a decreasing trend in rainfall at some stations and an increasing trend in temperature along with other factor. Belihu et al. (2018) and Jaweso et al. (2019) suggested the stream flow reduction might be related to the catchment dynamics especially land cover change and climate changes over the River basins.
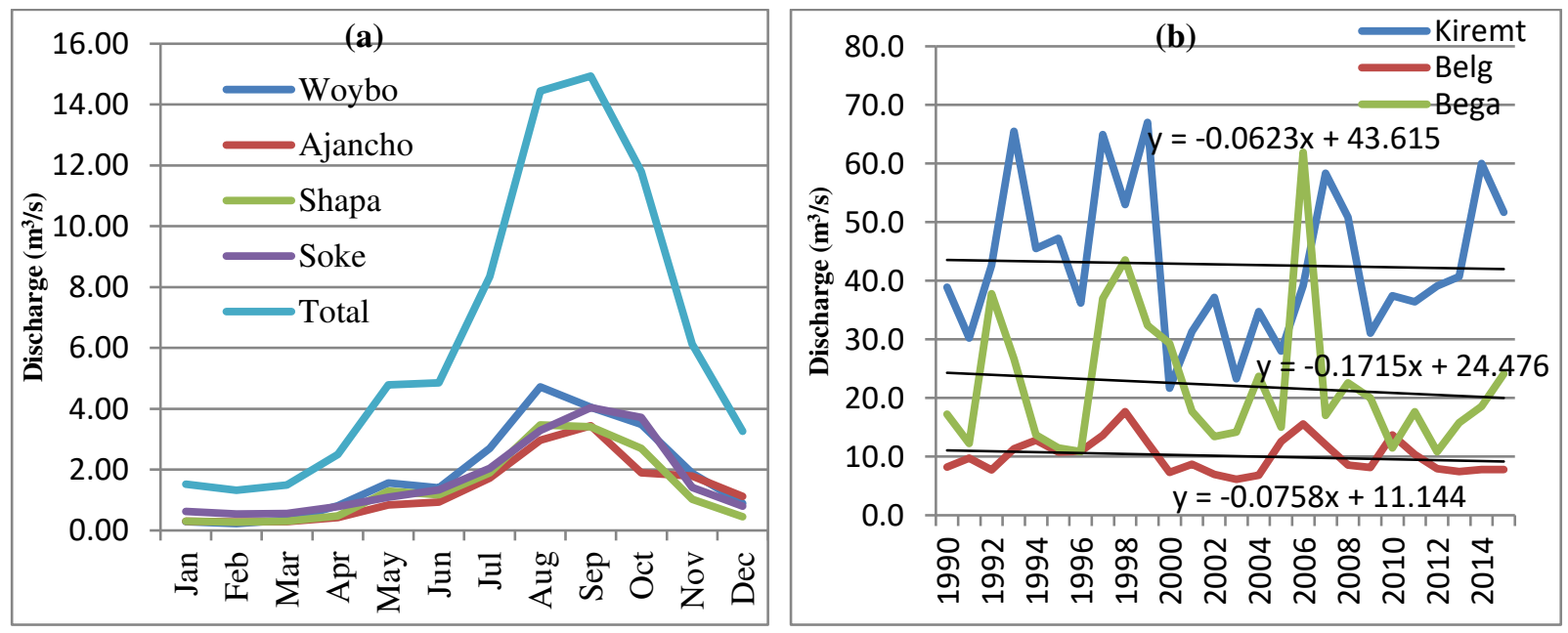

Figure 11. (a) Mean monthly discharge and (b) mean seasonal discharge of the watershed 
Table 9. MK test result of monthly and Seasonal discharge

\begin{tabular}{|c|c|c|c|c|c|c|c|c|c|c|c|c|c|c|c|c|}
\hline & \multicolumn{16}{|c|}{ Time } \\
\hline & Jan & Feb & Mar & Apr & May & Jun & Jul & Aug & Sep & Oct & Nov & Dec & Annual & Kiremt & Belg & Bega \\
\hline N่ & $\stackrel{\infty}{0}$ & $\stackrel{\infty}{\infty}$ & शे & $\begin{array}{l}0 \\
0 \\
\dot{1}\end{array}$ & $\stackrel{\infty}{+}$ & $\stackrel{\infty}{+}$ & $\frac{0}{0}$ & $\stackrel{+}{\stackrel{+}{0}}$ & $\stackrel{n}{+}$ & $\frac{0}{\stackrel{0}{0}}$ & $\begin{array}{l}0 \\
? \\
?\end{array}$ & 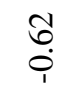 & $\stackrel{\overbrace{}}{T}$ & $\begin{array}{l}\infty \\
\widetilde{\gamma} \\
\text { i }\end{array}$ & $\stackrel{0}{\rightleftarrows}$ & $\begin{array}{l}\overline{0} \\
\dot{\varphi}\end{array}$ \\
\hline$\frac{\Xi}{\frac{0}{n}}$ & $\frac{8}{7}$ & $\underset{\sim}{\text { ָे }}$ & نجْ & $\begin{array}{l}\text { N } \\
\dot{\varphi}\end{array}$ & $\begin{array}{l}\text { ñ } \\
\text { ri }\end{array}$ & ָָ & $\begin{array}{l}\text { † } \\
\dot{1}\end{array}$ & 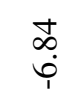 & ڤ̆ & 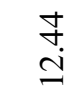 & $\begin{array}{l}\text { ळ } \\
\text { p. }\end{array}$ & $\frac{\infty}{\underset{1}{\sim}}$ & 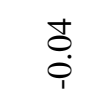 & $\overline{0}$ & 仓̊ & $\frac{N}{0}$ \\
\hline
\end{tabular}

\section{Correlation analysis between climate and River discharge}

Correlation between climate (rainfall and temperature) parameters and their impact in river discharge is a subject of ongoing debate (Jurgelenaite and Jakimavicius, 2014; Gedefaw et al., 2018). Therefore, the correlation between the climate variables and discharge help us to estimate their relations. The correlation between precipitation and river discharge $\left(\mathrm{R}^{2}=0.28\right)$ was found to be very weak in this study. Moreover, the correlation between temperature and runoff was also very weak $\left(\mathrm{R}^{2}=0.04\right)$. This shows that temperature plays a minor role in the increase and decrease of discharge. The decreasing trend in river discharge is likely related to the reduction of a long-term precipitation cycle (Chen and Grasby, 2014). The influence of rainfall on stream flow is weak and this reveals that other factors like evapotranspiration, soil infiltration and land use change may contribute (Gedefawu et al., 2018) and needed to be considered which does not the scope of this study. Therefore, the cause for this change needs further investigation.
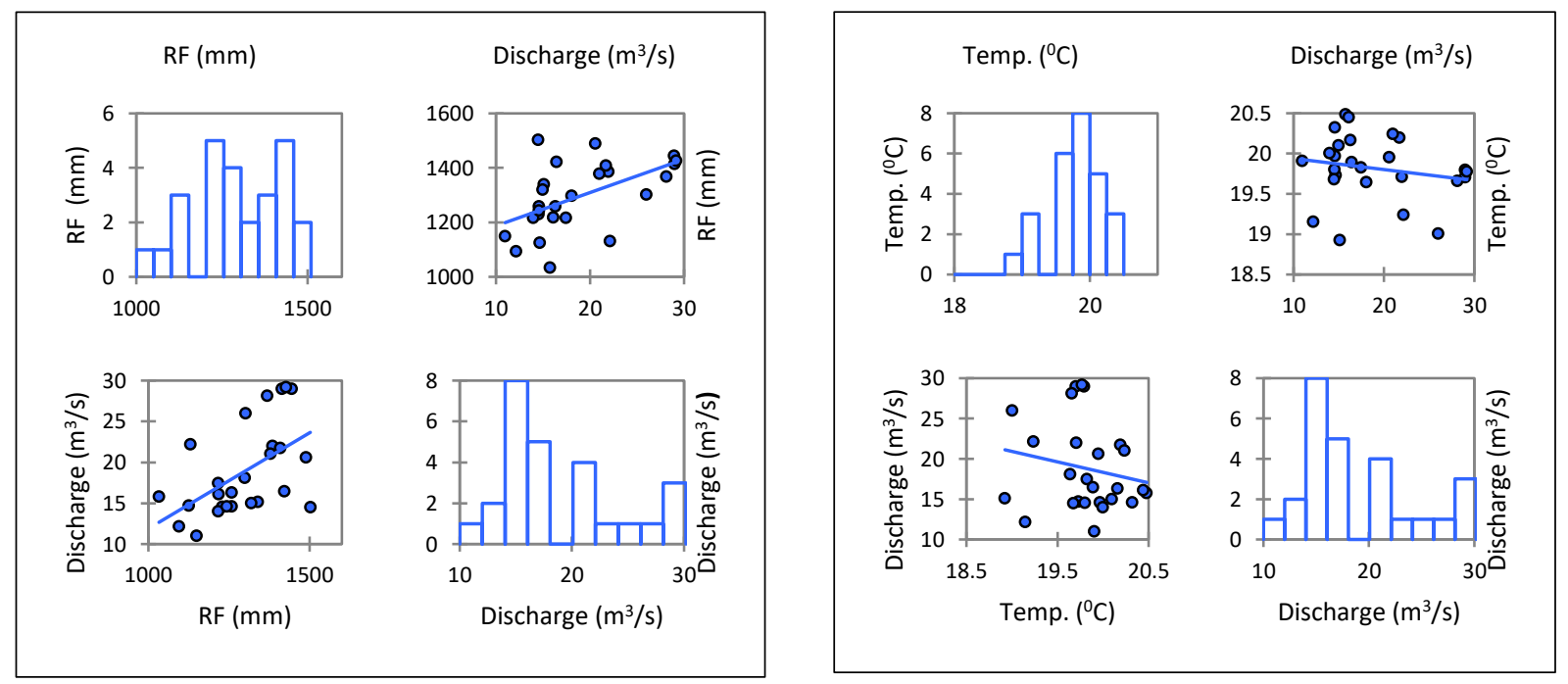

Figure 12. Correlation coefficient between rainfall with discharge and temperature with discharge 


\section{Conclusion}

This study investigated the trends of rainfall, temperature, and discharge in the Ajora-Woybo watershed during the period of 1990-2020. The annual time series were homogeneous from the majority of the stations. The annual, monthly and seasonal variability of parameters was investigated in all stations. There was inter-annual variability of rainfall, temperature, and discharge observed across the stations. The Mann-Kendall test and Sen's slope test analyses showed that decreasing and increasing trends of rainfall, temperature, and discharge were observed across the stations.

Results indicate that inhomogeneity was detected in annual rainfall data of Angacha and Areka stations. The rainfall is generally homogenous and declining annually but it was insignificant rate. The monthly RF is highest in august and lowest in December in all of the stations. Seasonally, the rainfall was found to be in Kiremt $(Z=2.78)$, Belg $(Z=-1.74)$ and Bega $(Z=-0.26)$. The temperature variability between the different years and the average annual temperature is $20.1{ }^{\circ} \mathrm{C}$, while the annual mean maximum temperature reached $25.7{ }^{\circ} \mathrm{C}$ and the annual mean minimum temperature was $14{ }^{\circ} \mathrm{C}$. The maximum, minimum and mean temperature trend was significantly increasing at the watershed level. From the minimum and maximum temperature trend, it was observed that the magnitude of change reaches about $0.01{ }^{0} \mathrm{C} / \mathrm{yr}$ to $0.04{ }^{0} \mathrm{C} / \mathrm{yr}$ and the mean values also proved that the watershed was warming at about $0.025^{0} \mathrm{C} / \mathrm{yr}$. The annual trend of discharge showed a decreasing trend from time to time. Mean annual flow of watershed was $75.2 \mathrm{~m}^{3} / \mathrm{s}$. Sen's slope of discharge show the month of September and October is upward magnitude whereas the remaining months show downward magnitude of trend. Generally monthly discharge shows decreasing trend except September and October. Kiremt season drains the highest amount of water and Belg season drains the lowest amount of waters in the watershed. The correlation of discharge with both rainfall ann temperature was found to be very weak in this study.

Overall, the results from the long-term analysis of hydro-meteorological variables in the AjoraWoybo watershed indicate a decrease in water resources. From the results, decrease in water resource due to climate change or land-use change may be detected in such a watershed. However, they are beyond the focus of this. For this purpose, additional driving factors should be investigated in the future study.

\section{Declarations}

Ethics approval and consent to participate: Not applicable for this section

Consent for publication: Not applicable for this section

Availability of data and materials: The data that support the findings of this study are available from Ministry of Water and Irrigation and National Meteorological Agency of Ethiopia but restrictions apply to the availability of these data, which were used under license for the current 
study, and so are not publicly available. Data are however available from the authors upon reasonable request and with permission of Ministry of Water and Irrigation and National Meteorological Agency of Ethiopia.

Competing interests: We wish to confirm that there are no conflicts of interest associated with this publication.

Funding: there has been no significant financial support for this work that could have influenced its outcome.

Author Contributions: Conceptualization, M.B.T., M.D.B. and M.D.U.; methodology, M.B.T.; software, M.B.T.; validation, M.B.T., M.D.B. and M.D.U; formal analysis, M.B.T.; investigation, M.B.T.; writing — original draft preparation, M.B.T.; writing—review and editing, M.B.T., M.D.B. and M.D.U.; supervision, M.D.B. and M.D.U. All authors have read and agreed to the published version of the manuscript.

Acknowledgments: We would like to thank, Ministry of Water and Irrigation Ministry and National Meteorological Agency of Ethiopia, for providing hydrological and meteorological data for the study.

Authors' information (optional): We the undersigned agree with all of the above. Author's name (First, Last) Signature Date

1. Meseret Bekele Toma

16 November 2021

2. Mulugeta Dadi Belete

16 November 2021

3. Mihret Dananto Ulsido

16 November 2021

\section{References}

Abegaz WB, Mekoya A (2020) Rainfall Variability and Trends over Central Ethiopia. Int J Environ Sci Nat Res 24(4).

Addisu S, Selassie YG, Fissha G, Gedif B (2015) Time series trend analysis of temperature and rainfall in lake Tana Sub-basin, Ethiopia. Environ System Res, 4:25.

Adeba D (2015) Assessment of water scarcity and its impacts on sustainable development in Awash basin, Ethiopia. Sustain. Water Resource Manag., 1, 71-87.

Alexanderson H (1986) A homogeneity test applied to precipitation data International Journal of Climatology 6, 661-675.

Alhaji UU, Yusuf AS, Edet CO, Oche CO, Agbo EP (2018) Trend Analysis of Temperature in Gombe State Using Mann Kendall Trend Test. Journal of Scientific Research \& Reports 20(3): 1-9.

Araya-Osses D, Casanueva A, Román-Figueroa C, Uribe JM, Paneque M (2020) Climate change 
projections of temperature and precipitation in Chile based on statistical downscaling. Climate Dynamics, 54:4309-4330.

Armanuos A M, Al-Ansari N, Yaseen ZM (2020) Cross Assessment of Twenty-One Different Methods for Missing Precipitation Data Estimation. Atmosphere, 11, 389.

Asfaw A, Simane B, Hassen A, Bantider A (2018) Variability and time series trend analysis of rainfall and temperature in north central Ethiopia: A case study in Woleka sub-basin. Weather and Climate Extremes 19, 29-41.

Bayable G, Amare G, Alemu G, Gashaw T (2021) Spatiotemporal variability and trends of rainfall and its association with Pacifc Ocean Sea surface temperature in West Harerge Zone, Eastern Ethiopia. Environ System Res, 10:7.

Belay A, Demissie T, Recha JW, Oludhe C, Osano PM, Olaka LA, Solomon D, Berhane Z (2021) Analysis of Climate Variability and Trends in Southern Ethiopia. Climate, 9, 96.

Belihu M, Abate B, Tekleab S, Bewket W (2018) Hydro-meteorological trends in the Gidabo catchment of the Rift Valley Lakes Basin of Ethiopia. Physics and Chemistry of the Earth, Volume 104, p. 84-101.

Bhuyan MDI, Islam M M and Bhuiyan MEK (2018) A Trend Analysis of Temperature and Rainfall to Predict Climate Change for Northwestern Region of Bangladesh. American Journal of Climate Change, 7, 115-134.

Bodian A, Diop L, Panthou G, Dacosta H, Deme A, Dezetter A, Ndiaye PM, Diouf I, Théo V (2020) Recent Trend in Hydro climatic Conditions in the Senegal River Basin. Water, 12, 436.

Chen Y, Marek GW, Marek Th H, Porter DO, Moorhead J E, Wang Q, Heflin K R Brauer D K (2020) Spatio-Temporal Analysis of Historical and Future Climate Data in the Texas High Plains. Sustainability, 12, 6036.

Chen Z, Grasby SE (2014) Reconstructing river discharge trends from climate variables and prediction of future trends. J. Hydrol., 511, 267-278.

Conway D, Schipper LEF (2011) Adaptation to climate change in Ethiopia: opportunities identified from Ethiopia, Global Environmental Change 21(1): 227- 237.

Degefu M A and Bewket W (2017) Variability, trends, and tele-connections of stream flows with large-scale climate signals in the Omo-Ghibe River Basin, Ethiopia. Environ. Monit. Assess, 189, 142. 
Ekeu-wei ITh, Blackburn GA Pedruco Ph (2018) Infilling Missing Data in Hydrology: Solutions Using Satellite Radar Altimetry and Multiple Imputation for Data-Sparse Regions. Water, 10, 1483.

Emmanuel LA, Hounguè NR, Biaou Ch A, Badou DF (2019) Statistical Analysis of Recent and Future Rainfall and Temperature Variability in the Mono River Watershed (Benin, Togo). Climate, 7, 8.

Fazzini M, Bisci C, Billi P (2015) The Climate of Ethiopia. Landscapes and Landforms of Ethiopia, World Geomorphological Landscapes, DOI 10.1007/978-94-017-8026-1_3.

Gedefaw M, Wang H, Yan D, Song X, Yan D, Dong G, Wang J, Girma A, Ali B, Batsuren D, Abiyu A, Qin T (2018) Trend Analysis of Climatic and Hydrological Variables in the Awash River Basin, Ethiopia. Water, 10, 1554.

Gizachew L, Shimelis A (2014). Analysis and mapping of climate change risk and vulnerability in central rift valley of Ethiopia. African Crop Science Journal, Vol. 22, Issue Supplement s4, pp. 807 -818 .

IPCC, 2014. Climate change 2014: impacts, adaptation, and vulnerability. Part B: regional aspects. Contribution of Working Group II to the Fifth Assessment Report of the Intergovernmental Panel on Climate Change (Barros, V.R., C.B. Field, D.J. Dokken, M.D. Mastrandrea, K.J. Mach, T.E. Bilir, M. Chatterjee, K.L. Ebi, Y.O. Estrada, R.C. Genova, B. Girma, E.S. Kissel, A.N. Levy, S. MacCracken, P.R. Mastrandrea, and L.L. White, Cambridge University Press, Cambridge, United Kingdom and New York, NY, USA, 688. Ed.

Jaweso D, Abate B, Bauwe A, Lennartz B (2019). Hydro-Meteorological Trends in the Upper OmoGhibe River Basin, Ethiopia. Water, 11, 1951.

Jurgelenaite A, Jakimavicius D (2014) Prediction of River Water Temperature and its Dependence on Hydro-Meteorological Factors. Environmental Research, Engineering and Management, No. 2(68), P. 5-14-24.

Kendall MG (1975) Rank Correlation Methods, 4th edition. London, U.K: Charles Griffin.

Mann HB (1945) Nonparametric Tests Against Trend, Econometrica, 13, 245-259.

Mubialiwo A, Onyutha Ch, Abebe A (2020) Historical Rainfall and Evapotranspiration Changes over Mpologoma Catchment in Uganda. Advances in Meteorology Volume, Article ID 8870935, 19 pages.

NMA (National Meteorological Agency) (2014) Hydro Meteorological Bulletin for March, 2014. Ethiopia. 
NMA (National Meteorological Services Agency) (2007) Climate change national adaption programme of action (NAPA) of Ethiopia. The federal democratic republic of Ethiopia (FDRE), ministry of water resource.

Pettitt A (1979) A non-parametric approach to the change-point problem, Journal of the Royal Statistical Society. Series C (Applied Statistics), 28(2), 126e135.

Philip OS (2019) Assessment of past and future climate change as projected by regional climate models and likely impacts over Kenya. PhD thesis. Kenyatta University. Kenya.

Rubin D (1987) Multiple Imputations for Non Responses in Surveys, vol. 2. Wiley, New York.

Sattari MT, Rezazadeh-Joudi A, Kusiak A (2017) Assessment of different methods for estimation of missing data in precipitation studies. Hydrology Research 48 (4), 1032-1044.

Schafer JL (1997) Analysis of Incomplete Multivariate Data. Chapman and Hall/ CRC.

Sen PK (1968) Estimates of the regression coefficient based on Kendall's tau, J. Am. Stat. Assoc., 63, 1379-1389.

Serdeczny O, Adams S, Baarsch F, Coumou D, Robinson A, Hare W, Michiel S, Mahe' P, Julia R (2016) Climate change impacts in Sub-Saharan Africa: from physical changes to their social repercussions. Regional Environ Change, DOI 10.1007/s10113-015-0910-2.

Temesgen D, Hassan RM, Alemu T, Yesuf M and Ringler C (2008) Analyzing the determinants of farmers' choice of adaptation methods and perceptions of climate change in the Nile basin of Ethiopia. IFPRI Discussion Paper 00798. Environment and Production Technology Division, Washington, DC.

Tesfaye S, Taye G, Birhane E, Zee S E (2019) Observed and model simulated twenty-first century hydro-climatic change of Northern Ethiopia. Journal of Hydrology: Regional Studies 22, 100595.

Toreti A, Kuglitsch FG, Xoplaki E, Della-Marta PM, Aguilar E, Prohom M, Luterbacher J (2011) A note on the use of the standard normal homogeneity test to detect inhomogeneities in climatic time series. Int J Climatol 31(4):630-632.

Twisa S, Buchroithner MF (2019) Seasonal and Annual Rainfall Variability and Their Impact on Rural Water Supply Services in the Wami River Basin, Tanzania. Water 2019, 11, 2055.

UNCHA (United Nations Office for the Coordination of Humanitarian Affairs) (2016) Ethiopia; Learning from the impact of past La-Nina Events. http://reliefweb.int/report/ethiopia/ethiopia-slowonset-natural-disaster-sep-2016. 
Viste E, Diriba K, Sorteberg A (2013) Recent drought and precipitation tendencies in Ethiopia. Theor. Appl. Climatol. 112, 535-551.

Witte JPM, Runhaar J, Ek R, Hoek van der DCJ, Bartholomeus RP, Batelaan O, van Bodegom, PM, Wassen MJ. van der Zee SE (2012) An ecohydrological sketch of climate change impacts on water and natural ecosystems for the Netherlands: bridging the gap between science and society. Hydrol. Earth Syst. Sci. 16, 3945-3957.

Woldesenbet TA, Elagib N A (2021) Analysis of climatic trends in the upper Blue Nile basin based on homogenized data. Theoretical and Applied Climatology volume 146, pages 767-780.

Worku FF, Werner M, Wright N, van der Zaag P Demissie SS (2014) Flow regime change in an endorheic basin in southern Ethiopia. Hydrol. Earth Syst. Sci., 18, 3837-3853.

Yue S, Wang CY (2004) The Mann-Kendall Test Modified by Effective Sample Size to Detect Trend in Serially Correlated Hydrological Series. Water Resources Management, v.18, p.201-218. 